\title{
Single Source Multi-Frequency AC-AC Converter for Induction Cooking Applications
}

\author{
Pradeep Vishnuram ${ }^{1}{ }^{1}$, Suchitra Dayalan ${ }^{1}$, Sudhakar Babu Thanikanti ${ }^{2}$, Karthik Balasubramanian ${ }^{3}$ \\ and Benedetto Nastasi ${ }^{4, * \text { (D) }}$ \\ 1 Department of Electrical and Electronics Engineering, SRM Institute of Science and Technology, \\ Chennai 603203, India; pradeep.kannan03@gmail.com (P.V.); such1978@yahoo.com (S.D.) \\ 2 Department of Electrical and Electronics Engineering, Chaitanya Bharathi Institute of Technology (CBIT), \\ Hyderabad 500075, India; sudhakarbabu@ieee.org \\ 3 Design and Engineering (Electrical), Offshore Technology Development Private Limited, Keppel Offshore and \\ Marine Limited, Singapore 629353, Singapore; karthik017@e.ntu.edu.sg \\ 4 Department of Planning, Design, and Technology of Architecture, Sapienza University of Rome, \\ Via Flaminia 72, 00196 Rome, Italy \\ * Correspondence: benedetto.nastasi@outlook.com
}

Citation: Vishnuram, P.; Dayalan, S.; Thanikanti, S.B.; Balasubramanian, K.; Nastasi, B. Single Source

Multi-Frequency AC-AC Converter for Induction Cooking Applications. Energies 2021, 14, 4799. https:// doi.org/10.3390/en14164799

Academic Editors: Geun Young Yun and Seung Hyun Cha

Received: 11 May 2021

Accepted: 2 August 2021

Published: 6 August 2021

Publisher's Note: MDPI stays neutral with regard to jurisdictional claims in published maps and institutional affiliations.

Copyright: (c) 2021 by the authors. Licensee MDPI, Basel, Switzerland. This article is an open access article distributed under the terms and conditions of the Creative Commons Attribution (CC BY) license (https:// creativecommons.org/licenses/by/ $4.0 /)$.
Abstract: In recent years, induction heating (IH) applications aided by electronic power control have gained significance. Particularly, for cooking applications, an appropriate control technique is required to feed power from a single source to multiple loads with minimum switching losses. Additionally, when multiple loads are used, it requires independent control and operation for each of the loads. The main idea of this work is to develop a single-stage AC-AC converter topology to feed power to multiple loads independently with a single source, with a reduced number of switching devices and with minimum switching losses. The proposed topology uses a frequency bifurcation concept to feed power to multiple loads by placing the transmitting coil and work coil at a distance of $3 \mathrm{~cm}$. The source is resonated at a $25 \mathrm{kHz}$ switching frequency, with the designed bifurcated frequencies of $20 \mathrm{kHz}$ and $33 \mathrm{kHz}$. The resonant capacitors are appropriately chosen to operate at those frequencies. For real-time applications, simultaneous and independent power control are inevitable in multi load-fed IH applications. This is achieved through a pulse density modulation scheme with minimum switching losses. The simulation of the proposed system is performed in MATLAB/Simulink, and also the $1 \mathrm{~kW}$ system is validated using a PIC16F877A microcontroller. The real-time thermal variation in the load is also recorded using a FLIR thermal imager. The experimental and simulation results are observed, and the obtained efficiency of the system is plotted for various duty cycles of pulse density modulation control.

Keywords: frequency bifurcation; induction heating; independent power control; pulse density modulation; single source multi-frequency

\section{Introduction}

In the new era, domestic Induction Heating applications are replacing the traditional electric and gas heating technology. The induction heating system has the inherent benefits of higher conversion efficiency with a lower time constant to achieve the required cleaner heating. Based on the IH application, it requires a high bandwidth inverter ranging from $20 \mathrm{kHz}$ to $100 \mathrm{kHz}$. A typical IH system has a very high-power handling capacity of up to $500 \mathrm{~kW}$ [1,2]. In two-power conversion, commercial $50 \mathrm{~Hz} \mathrm{AC}$ is rectified, filtered, and converted into High-Frequency AC (HFAC). This results in more power losses, and further, the bulky capacitor increases the system time constant with a lesser source side power factor $[3,4]$. Thus, a selective harmonic elimination control technique is used to improve the source side power factor [5].

Various converter topologies, such as class E, class D, and full-bridge inverter fed topologies, were proposed in [6,7] and various power control techniques were used to 
control the output power [8,9]. The choice of the inverter depends primarily on the cost and the selected application. These topologies resulted in more losses due to AC-DC-AC power conversion. Thus, direct AC-AC converter topologies were proposed with a lesser number of components and with DC-link storage requirements [10,11]. The IH system's efficiency depends not only on the topology, but also on the control algorithms used for regulating the output power [12]. It plays a crucial role in regulating the temperature according to the load requirements. This can be accomplished by adjusting the angle of current or phase angle between voltage and current or the frequency of the supply.

The most widely used method to control the output power is the Pulse Width Modulation (PWM) technique $[13,14]$. This technique is very simple and gives a cost-effective solution for controlling the output power. Hard switching is the key downside to these control systems, which increases switching losses. Thus, this problem is overcome by a variable frequency control scheme with Phase Locked Loop (PLL) for regulating the output power [15]. PLL helps in tracking the resonant frequency as and when the load varies. However, this control scheme results in acoustic noise and EMI problems in the system. Hence, the converter is manufactured using GaN devices [16]. The operating frequency is varied from $20 \mathrm{kHz}$ to $500 \mathrm{kHz}$. The system possesses fast switching transients with high reliability.

Phase Shift Control (PSC) is constant frequency control, in which output power control is performed by adjusting the phase shift of the inverter pulses $[17,18]$. Though this method possesses smooth power control without an EMI problem, the source side power is found to be much lesser. This problem is resolved by using the Asymmetrical Voltage Cancelation (AVC) technique $[19,20]$. In this method, the output voltage waveform is made asymmetric by adjusting the duty cycle of the inverter. This results in the larger dead band either in the positive or negative cycle for the zero crossings of the current. Due to the asymmetric voltage, the DC components are injected into the system. This issue was overcome by Pulse Density Modulation (PDM) control [21,22]. The output power is controlled by varying the density of the switching pulses without distributing the switching frequency. This method guarantees reliable and seamless output power control with lesser switching losses.

In a recent scenario, IH systems with multi burners (more than two) are preferred for cooking applications. The selection of appropriate control techniques for feeding power to multiple loads remains a typical problem in real time. A two-load IH system is proposed by Forest F et al. in [23] by considering one load as a master and the other load as a slave. The resonant frequency of the load was varied by connecting additional capacitors using electro-mechanical switches to control the output power. This resulted in higher costs with a complex control. Sarnago et al. proposed an AC-AC converter for feeding power to two loads. PWM and PDM control techniques were used to control the output power and it was varied from $20 \%$ to $80 \%$ of the rated power [7]. The converter was tested with different frequencies which resulted in switching losses. In [24], a two-output Series Resonant Inverter (SRI) was proposed by Burdio et al. A high-frequency inverter was developed to feed power to two loads with the output power control using the AVC control technique. The main drawback of this scheme was cross interference as two loads were used. Hence, it is necessary to develop a simple control technique for mitigating the interference issue when multiple loads are used.

In the literature, various methods are used to reduce the cross-interference for wireless applications. One among them is by configuring the separate magnetic flux path for each load. This is achieved by designing the secondary receiver with an E-shaped ferromagnetic core [25]. However, this technique is limited to low-power applications. For high-power applications, a novel control scheme is developed for extracting the maximum power from the source with minimum cross-coupling [26]. Though the system works satisfactorily, designing a control circuit remains complex for real-time applications. Thus, a multisource fed system with multi-frequency was developed with various transmitters and receivers [27]. This resulted in lesser magnetic flux linkage and, due to higher number of coils, the associated efficiency was also reduced. To avoid cross-coupling across the loads, 
frequency bifurcation phenomena were used in wireless power transfer applications [28,29]. This concept was used in [30] for a wireless power transfer system with double, triple, and quadruple coils. The expressions for obtaining the coupling distance were obtained for different coils based on the system.

It is evident from the literature that there is a quest to propose a method to feed power to multiple loads with a single frequency to avoid the cross inference of supply. Hence, this work proposes the frequency bifurcation phenomena for feeding power to multiple loads with an AC-AC converter and controlling the output power with PDM control logic. The proposed control scheme provides a smooth power control with minimum switching losses for a multi-load fed IH system. The most significant contribution of this work is to analyze the performance of the control scheme for the single-stage AC-AC converter topology with a reduced number of semiconductor switches and to control the output power simultaneously and independently. The simulation of the system is tested with a 1 $\mathrm{kW}$ power rating in MATLAB Simulink and real-time implementation is carried out using a PIC16F877A microcontroller. The following points are unique with respect to the work:

$>$ The control algorithm feeds power to two loads with a single frequency source.

$>$ At rated power, the system possesses $5 \%$ lower power losses as compared with the existing articles [31,32].

$>$ The efficiency of the system is greater than $92 \%$ for $0 \%$ to $100 \%$ of the rated power.

$>$ As switching frequency is not varied, soft switching is realized for the whole operating range.

The course of this paper is organized as follows: Section 2 describes the system description of a single-stage AC-AC converter. Simulation and experimental validation of the control technique are performed in Section 3. The conclusion of the paper is presented in Section 4.

\section{System Description}

The circuit diagram of the proposed converter topology and its complete working details with specifications are described in the following sub-section.

\subsection{Circuit Description}

The single-stage AC-AC resonant converter proposed in this work converts $50 \mathrm{~Hz}$ AC directly into HFAC without a rectifier unit. This avoids the power conversion losses and reduces the number of semiconductor switches which improves the system overall efficiency. For IH application, this topology is most suitable, as power conversion takes place with higher efficiency. The circuit diagram of the single-stage AC-AC converter is shown in Figure 1. It has four IGBTs for converting the $50 \mathrm{~Hz}$ AC to HFAC. The inductor $\mathrm{L}_{\mathrm{S}}$ acts as the primary coil for transferring power to IH load. The purpose of the sourceside inductor $\left(\mathrm{L}_{\mathrm{S}}\right)$ is to transmit the HFAC supply to IH coil. To create resonance in the transmitter circuit, a capacitor $\left(C_{s}\right)$ is used. The transmitter coil is driven with IGBT switches to produce HFAC. The output voltage of the transmitter is represented as $\mathrm{v}_{\mathrm{ab}}$. The equivalent circuit of a two-load fed IH system with a transmitter is shown in Figure 2. $\mathrm{M}_{12}$ and $\mathrm{M}_{13}$ represent the mutual inductance of load 1 and load 2 with respect to the source inductance. The equivalent inductances of load 1 and load 2 are represented as $\mathrm{L}_{\mathrm{eq} 1}$ and $\mathrm{L}_{\mathrm{eq} 2}$, and the equivalent resistances are $\mathrm{R}_{\mathrm{eq} 1}$ and $\mathrm{R}_{\mathrm{eq} 2}$. The resonant capacitors of load 1 and load 2 are represented as $C_{\mathrm{r} 1}$ and $C_{\mathrm{r} 2}$, respectively. The inverter is triggered in such a manner that $50 \mathrm{~Hz}$ AC is converted into HFAC. The switching pulses, typical voltage, and current waveforms are shown in Figure 3. 


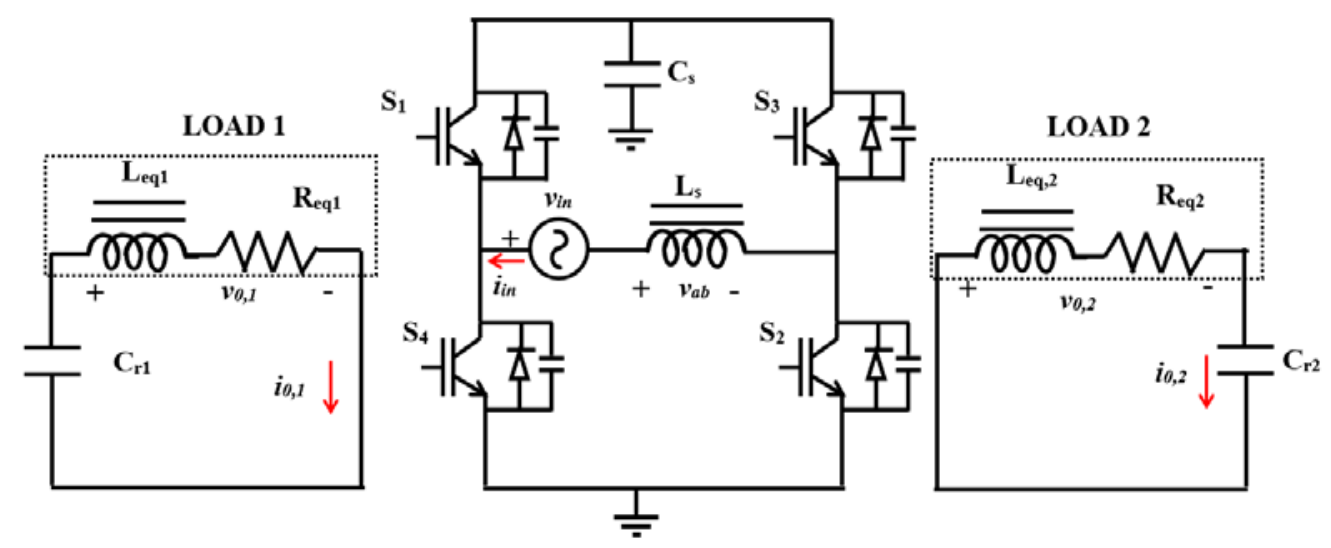

Figure 1. Circuit diagram of single-stage AC-AC converter.

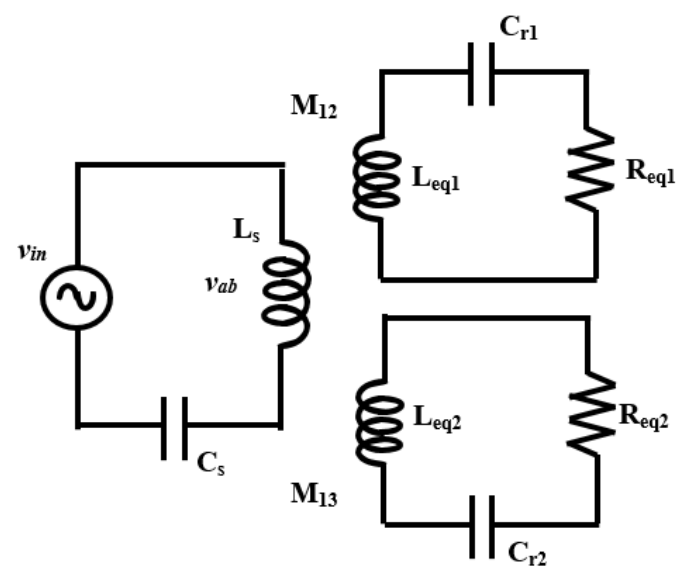

Figure 2. Equivalent circuit of two loads fed IH system.

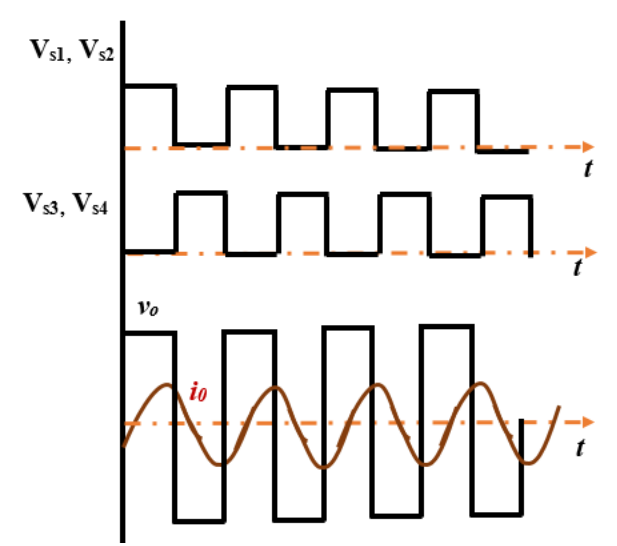

Figure 3. Typical voltage and current waveforms.

\subsection{Induction Heating Modeling}

The principle of induction heating resembles the operation of a magnetically coupled transformer where the primary and secondary windings serve to match the source and load voltage. The primary winding is recognized as a work coil and the vessel pan acts as the secondary. In the primary of the transformer, a high-frequency AC is fed and thus eddy currents are generated in the short-circuited secondary side. The heat exerted by the eddy current is channelized and used in heating applications. In order to minimize the complexity of testing the load parameters, it can be represented in the analogous transformer model. The IH cooking system is represented as the reflected parameters of $R_{\text {eq }}$ and $L_{\text {eq }}$ which are the equivalent parameters of the work coil and work piece. An 
equivalent model of IH for load 1 is shown in Figure 4 . The output voltage of load 1 is represented as $\mathrm{v}_{0,1}$, and $\mathrm{R}_{\mathrm{p} 1}$ and $\mathrm{L}_{\mathrm{p} 1}$ represent the work coil resistance and inductance of load 1 . The secondary side (Load) resistance and inductance of load 1 are represented as $R_{s 1}$ and $L_{p 1}$, respectively. The mutual inductance of load 1 is denoted as $M_{11}$.

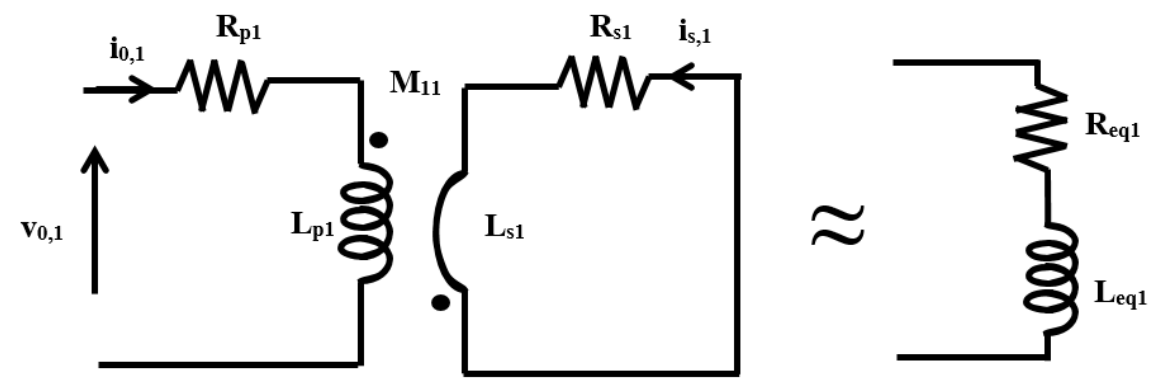

Figure 4. Equivalent model of IH load 1.

Applying KVL to the equivalent circuit of load 1, which is shown in Figure 3

$$
\begin{gathered}
\left(R_{p 1}+j \omega_{s 1} L_{p 1}\right) i_{0,1}-j \omega_{s 1} M_{11} i_{s, 1}=v_{0,1} \\
\left(R_{s 1}+j \omega_{s 1} L_{s 1}\right) i_{s, 1}-j \omega_{s 1} i_{0,1} M_{11}=0
\end{gathered}
$$

The angular switching frequency of load $1\left(\omega_{\mathrm{s} 1}\right)$ is

$$
\omega_{\mathrm{s} 1}=2 \pi \mathrm{f}_{\mathrm{s} 1}
$$

The current flowing through the load 1 is

$$
i_{s, 1}=\frac{j \omega_{s 1} M_{11} i_{0}}{R_{s 1}+j \omega_{s 1} L_{s 1}}
$$

Substituting Equation (4) into Equations (1) and (2),

$$
\mathrm{v}_{0,1}=\left(\mathrm{R}_{\mathrm{p} 1}+\frac{\omega_{\mathrm{s} 1}^{2} \mathrm{M}_{11}^{2} \mathrm{R}_{\mathrm{s} 1}}{\mathrm{R}_{\mathrm{s} 1}^{2}+\omega_{\mathrm{s} 1}^{2} \mathrm{~L}_{\mathrm{s} 1}^{2}}+j \omega_{\mathrm{s} 1}\left[\mathrm{~L}_{\mathrm{p} 1}+\frac{\omega_{\mathrm{s} 1}^{2} \mathrm{M}_{11}^{2} \mathrm{~L}_{\mathrm{s} 1}}{\mathrm{R}_{\mathrm{s} 1}^{2}+\omega_{\mathrm{s} 1}^{2} \mathrm{~L}_{\mathrm{s} 1}^{2}}\right]\right) \mathrm{i}_{0,1}
$$

$\mathrm{R}_{\mathrm{eq} 1}$ and $\mathrm{L}_{\mathrm{eq} 2}$ are obtained by the real and imaginary terms,

$$
\begin{aligned}
& \mathrm{R}_{\mathrm{eq} 1}=\mathrm{R}_{\mathrm{p} 1}+\frac{\omega_{\mathrm{s} 1}^{2} \mathrm{M}_{11}{ }^{2} \mathrm{R}_{\mathrm{s} 1}}{\mathrm{R}_{\mathrm{s} 1}^{2}+\omega_{\mathrm{s} 1}^{2} \mathrm{~L}_{\mathrm{s} 1}^{2}} \\
& \mathrm{~L}_{\mathrm{eq} 1}=\mathrm{L}_{\mathrm{p} 1}+\frac{\omega_{\mathrm{s} 1}^{2} \mathrm{M}_{11}{ }^{2} \mathrm{~L}_{\mathrm{s} 1}}{\mathrm{R}_{\mathrm{s} 1}^{2}+\omega_{\mathrm{s} 1}^{2} \mathrm{~L}_{\mathrm{s} 1}^{2}}
\end{aligned}
$$

The equivalent impedance of load $1\left(\mathrm{Z}_{\mathrm{eq} 1}\right)$ with the resonant capacitor $\left(\mathrm{C}_{\mathrm{r} 1}\right)$ is

$$
Z_{\mathrm{eq} 1}=R_{\mathrm{p} 1}+\frac{\omega_{\mathrm{s} 1}^{2} \mathrm{M}_{11}^{2} \mathrm{R}_{\mathrm{s} 1}}{\mathrm{R}_{\mathrm{s} 1}^{2}+\omega_{\mathrm{s} 1}^{2} \mathrm{~L}_{\mathrm{s} 1}^{2}}+j \omega_{\mathrm{s} 1}\left(\mathrm{~L}_{\mathrm{p} 1}+\frac{\omega_{\mathrm{s} 1}^{2} \mathrm{M}_{11}^{2} \mathrm{~L}_{\mathrm{s} 1}}{\mathrm{R}_{\mathrm{s} 1}^{2}+\omega_{\mathrm{s} 1}^{2} \mathrm{~L}_{\mathrm{s} 1}^{2}}-\frac{1}{\omega_{\mathrm{s} 1}^{2} \mathrm{C}_{\mathrm{r} 1}}\right)
$$

The output current flowing through load $1\left(\mathrm{i}_{01}\right)$ is

$$
\mathrm{i}_{01}=\frac{\mathrm{v}_{01}}{\left|\mathrm{Z}_{\mathrm{eq} 1}\right|}
$$

The output power of load 1 is

$$
\mathrm{P}_{01}=\mathrm{i}_{01}^{2} \mathrm{R}_{\mathrm{eq} 1}
$$


The output power computation for load 2 can be performed by replacing the subscript ' 1 ' with ' 2 ' in Equations (1)-(10). The equivalent circuit of an IH system with a transmitter coil and IH system is shown in Figure 4. The inverter switches are triggered in such a manner that $50 \mathrm{~Hz} \mathrm{AC}$ is converted into HFAC.

An equivalent model IH system with a transmitter is shown in Figure 5. By applying KVL and solving the expressions as in Equations (1)-(7), the equivalent input impedance $\left(\mathrm{Z}_{\mathrm{in} 1}\right)$ by considering load 1 alone is

$$
Z_{\text {in } 1}=\frac{\omega_{\mathrm{s}}^{2} \mathrm{M}_{12}^{2} \mathrm{R}_{\mathrm{eq} 1}}{\mathrm{R}_{\mathrm{eq} 1}^{2}+\omega_{\mathrm{s}}^{2} \mathrm{~L}_{\mathrm{eq} 1}^{2}}+j \omega_{\mathrm{s} 1}\left(\mathrm{~L}_{\mathrm{s}}+\frac{\omega_{\mathrm{s}}^{2} \mathrm{M}_{12}^{2} \mathrm{~L}_{\mathrm{eq} 1}}{\mathrm{R}_{\mathrm{s} 1}^{2}+\omega_{\mathrm{s}}^{2} \mathrm{~L}_{\mathrm{eq} 1}^{2}}-\frac{1}{\omega_{\mathrm{s}}^{2} \mathrm{C}_{\mathrm{r} 1}}+\frac{1}{\omega_{\mathrm{s}}^{2} \mathrm{C}_{\mathrm{s}}}\right)
$$

Similarly, equivalent input impedance $\left(Z_{\text {in } 2}\right)$ by considering load 2 alone is

$$
Z_{\mathrm{in} 2}=\frac{\omega_{\mathrm{s}}^{2} \mathrm{M}_{13}{ }^{2} \mathrm{R}_{\mathrm{eq} 2}}{\mathrm{R}_{\mathrm{eq} 2}^{2}+\omega_{\mathrm{s}}^{2} \mathrm{~L}_{\mathrm{eq} 2}^{2}}+j \omega_{\mathrm{s} 1}\left(\mathrm{~L}_{\mathrm{s}}+\frac{\omega_{\mathrm{s}}^{2} \mathrm{M}_{13}{ }^{2} \mathrm{~L}_{\mathrm{eq} 2}}{\mathrm{R}_{\mathrm{s} 1}^{2}+\omega_{\mathrm{s}}^{2} \mathrm{~L}_{\mathrm{eq} 2}^{2}}-\frac{1}{\omega_{\mathrm{s}}^{2} \mathrm{C}_{\mathrm{r} 2}}+\frac{1}{\omega_{\mathrm{s}}^{2} \mathrm{C}_{\mathrm{s}}}\right)
$$

The input current $\left(\mathrm{i}_{\text {in }}\right)$ is given by

$$
\mathrm{i}_{\text {in }}=\frac{\mathrm{v}_{\text {in }}}{\left|\mathrm{Z}_{\mathrm{in} 1}+\mathrm{Z}_{\mathrm{in} 2}\right|}
$$

As the transmitter is triggered at resonance frequency, the input power is given by

$$
\mathrm{P}_{\text {in }}=\mathrm{V}_{\text {in }} \mathrm{I}_{\text {in }}
$$

where $V_{\text {in }}$ and $I_{\text {in }}$ are the rms value of input voltage and current.

The efficiency of IH system is

$$
\eta_{1}=\frac{P_{01}+P_{02}}{P_{\text {in }}}
$$

The efficiency of the system is calculated by considering the conduction loss as expressed in Equation (15).

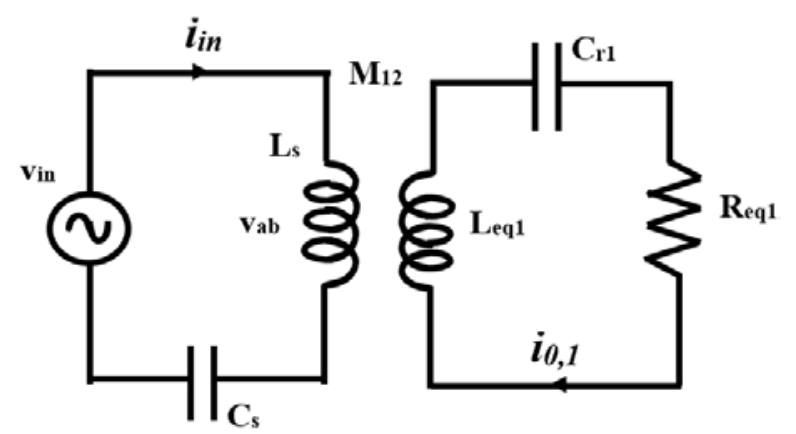

Figure 5. Equivalent model of IH system with transmitter.

\subsection{Frequency Bifurcation of a Two Coil-Based IH System}

Frequency bifurcation is a phenomenon in which frequency of the output power splits from single frequency into dual frequency. This is achieved by adjusting the coupling distance between work coil and work piece (load) greater than the coupling coefficients. The prime concept which lies behind it is the magnetic resonance coupling of the system, which results in improved efficiency without cross interference of the frequency across the loads. Frequency bifurcation represents the input characteristic of the system. In 
order to analyze the system characteristics, the real-time system is tested with the design specification listed in Table 1 . The coupling coefficient for coil and load 1 is [30]

$$
\mathrm{K}_{12}=\frac{\omega_{\mathrm{s}}}{1+\frac{2^{1.5} \mathrm{~d}_{12}^{2}}{\mathrm{R}_{\mathrm{s}} \mathrm{R}_{\mathrm{eq} 1}}}
$$

The coupling coefficient for coil and load 2 is [30]

$$
\mathrm{K}_{13}=\frac{\omega_{\mathrm{s}}}{1+\frac{2^{1.5} \mathrm{~d}_{13}^{2}}{\mathrm{R}_{\mathrm{s}} \mathrm{R}_{\mathrm{eq} 2}}}
$$

where $d_{12}$ is distance between the source and load 1 and $d_{13}$ is distance between source and load 2.

The bifurcated output frequency of load 1 is [30]

$$
\omega_{01}=\frac{\omega_{\mathrm{s}}}{1+\sqrt{\mathrm{K}_{12}^{2}+\mathrm{K}_{13}^{2}}}
$$

The bifurcated output frequency of the load 2 is [30]

$$
\omega_{02}=\frac{\omega_{\mathrm{s}}}{1-\sqrt{\mathrm{K}_{12}^{2}+\mathrm{K}_{13}^{2}}}
$$

Expressions (16) and (17) formulate the relationship between the distance between the source load with the source frequency. In [30], the authors have formulated the relation for the coupling coefficient and source frequency as given in Equations (18) and (19). In this work, the expression is directly used and validated. It is observed that, by locating the transmitting coil and work coil at a distance of $3 \mathrm{~cm}$, the source frequency $(25 \mathrm{kHz})$ is bifurcated as $20 \mathrm{kHz}$ and $33 \mathrm{kHz}$ frequency. These frequencies are used to feed power to

\begin{tabular}{|c|c|c|}
\hline Components & Load 1 & Load 2 \\
\hline Equivalent load resistance, $R_{\mathrm{eq}}$ & $11 \Omega$ & $11 \Omega$ \\
\hline Equivalent load inductance, $\mathrm{L}_{\mathrm{eq}}$ & $0.12 \mathrm{mH}$ & $0.12 \mathrm{mH}$ \\
\hline Resonant capacitor, $\mathrm{C}_{\mathrm{r}}$ & $520 \mathrm{nF}$ & $200 \mathrm{nF}$ \\
\hline Input inductor, $\mathrm{L}_{\mathrm{S}}$ & \multirow{2}{*}{\multicolumn{2}{|c|}{$\begin{array}{c}200 \mu \mathrm{H} \\
200 \mathrm{nF}\end{array}$}} \\
\hline Source capacitor $\mathrm{C}_{\mathrm{s}}$ & & \\
\hline
\end{tabular}
load 1 and load 2 by selecting appropriate capacitors to handle the loads independently. That real-time validation is performed in a further section.

Table 1. Design specifications of AC-AC converter.

\section{Simulation and Experimental Results}

A single-stage AC-AC inverter-fed induction cooking device is typically implemented to operate with HFAC of $25 \mathrm{kHz}$ frequency. The inverter pulses are triggered in such a way that the $S_{1}$ and $S_{2}$ are turned on for a positive half cycle and $S_{3}$ and $S_{4}$ are turned on for a negative half cycle of the HFAC. Due to this switching action, a $50 \mathrm{~Hz}$ AC is chopped into a $25 \mathrm{kHz}$ frequency AC. The system is validated by keeping the transmitter coil and work coil at a $3 \mathrm{~cm}$ distance. The resonant frequencies of load 1 and load 2 are designed for $20 \mathrm{kHz}$ and $33 \mathrm{kHz}$. Hence, the capacitors are chosen to operate at that frequency. The output power is performed using the PDM control technique to have smooth control with fewer switching losses [22]. In compliance with the design requirements in Tables 1 and 2, the single-stage inverter with PDM control is simulated in the MATLAB/Simulink software. A PIC16F877A Controller with the TLP250 Driver IC is used to validate the control mechanism. Four H20R1203 IGBT control switches that can handle $1200 \mathrm{~V}$ and $25 \mathrm{~A}$ are part of the key circuit. For measuring the current, the SIGLENT CP4060 current probe is used, and the 
oscilloscope is used for capturing waveforms. The advanced FLIR E75 $24^{\circ}$ thermal camera is used to record the thermal image of the load in real time. The configuration for the test setup is shown in Figure 6.

Table 2. Specific requirements.

\begin{tabular}{cc}
\hline Parameters & Value \\
\hline $\mathrm{V}_{\text {in }}$ & $230 \mathrm{~V}(\mathrm{RMS}), 50 \mathrm{~Hz}$ \\
$\mathrm{P}_{\text {rat }}$ & $1000 \mathrm{~W}$ \\
$\mathrm{f}_{\mathrm{PDM}}$ & $25 \mathrm{~Hz}$ \\
$\mathrm{f}_{\mathrm{r}}$ & $25 \mathrm{kHz}$ \\
$\mathrm{f}_{\mathrm{r} 1}$ & $20 \mathrm{kHz}$ \\
$\mathrm{f}_{\mathrm{r} 2}$ & $33 \mathrm{kHz}$ \\
\hline
\end{tabular}

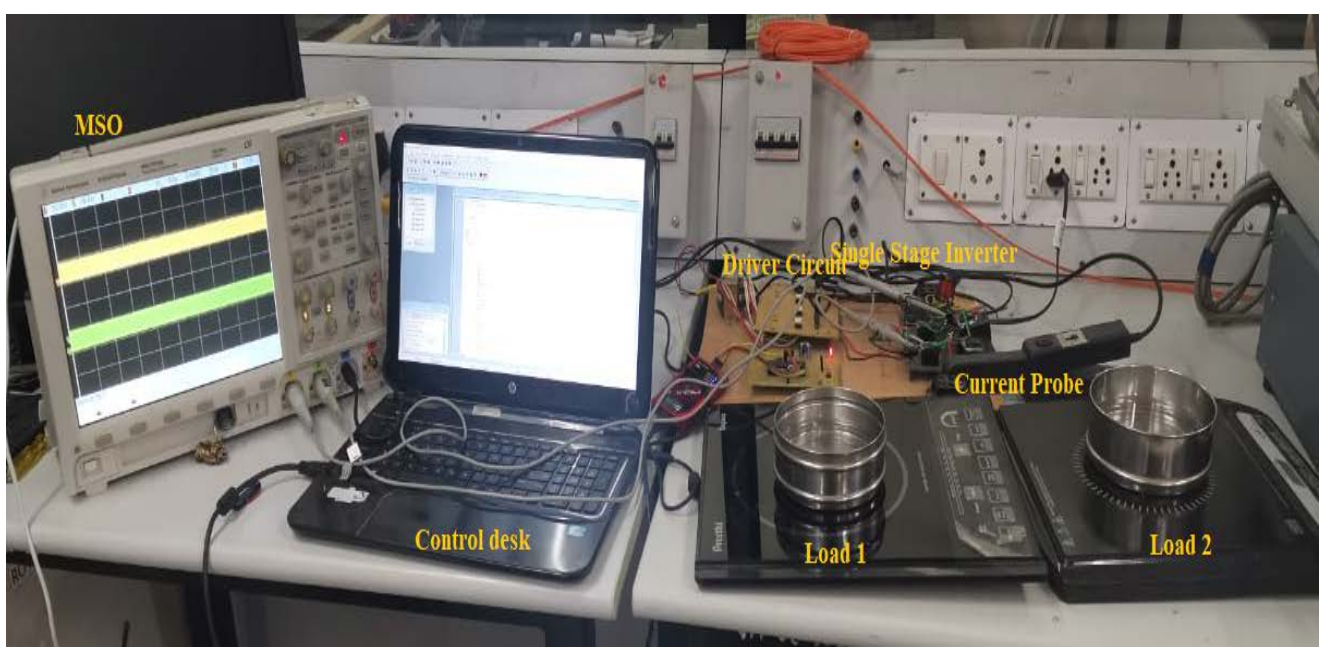

Figure 6. The test set up of the IH system.

\subsection{Dual Load Operation}

A simulation of the proposed system is performed in MATLAB/Simulink. The simulated switching pulses $\left(V_{\mathrm{s} 1}, V_{\mathrm{s} 2}, \mathrm{~V}_{\mathrm{s} 3}, \mathrm{~V}_{\mathrm{s} 4}\right)$ for the switches $\mathrm{S}_{1}, \mathrm{~S}_{2}$. $\mathrm{S}_{3}$ and $\mathrm{S}_{4}$ are shown in Figure $7 \mathrm{a}$ and its associated waveforms of voltage and currents for load 1 and load 2 are shown in Figure $7 b, c$, respectively. In Figure $7 d$, the expanded waveform of output voltage $\left(\mathrm{v}_{0,1}\right)$ and current $\left(\mathrm{i}_{\mathrm{o}, 1}\right)$ waveform for load 1 is demonstrated. Similarly, in Figure $7 \mathrm{e}$, the enhanced view of output voltage $\left(\mathrm{v}_{0,2}\right)$ and current $\left(\mathrm{i}_{0,2}\right)$ waveform for load 2 is shown. In real time, the system is tested for $1000 \mathrm{~W}$ and the test results of switching pulses are illustrated in Figure $7 \mathrm{f}$. The output voltage and current waveform for load 1 and load 2 are presented in Figure $7 \mathrm{~g}, \mathrm{~h}$, respectively. The zoomed view of experimental voltage and current waveform of load 1 is shown in Figure $7 i$ and load 2 is shown in Figure 7j. It is observed from the output voltage and waveforms that the envelope follows the $50 \mathrm{~Hz}$ sinusoidal AC waveform and there is a chopping of high-frequency signal within one complete cycle. The capacitor of each load is chosen in such a manner that it acts as the minimum reactance path for its resonant frequency and open circuit for other frequencies. It enumerates that load 1 responds to $20 \mathrm{kHz}$ frequency, whereas load 2 responds to $33 \mathrm{kHz}$ supply. For other frequencies, the loads remain open circuit. The rms value of the load 1 current is $\mathrm{I}_{0,1 \mathrm{rms}}$ is $7.07 \mathrm{~A}$ and $\mathrm{I}_{0,2 \mathrm{rms}}$ is $6.36 \mathrm{~A}$. The output power $\mathrm{P}_{0,1}=7.07^{2} \times 11=550 \mathrm{~W}$ and $\mathrm{P}_{0,2}=6.36^{2} \times 11=445 \mathrm{~W}$ for $11 \Omega$ equivalent resistance. The total input power is $\mathrm{P}_{\text {in }}=\mathrm{V}_{\text {in }} \times \mathrm{I}_{\text {in }}=1050.69 \mathrm{~W}$ and efficiency is $94.7 \%$. The current spectrum of load 1 and load 2 are illustrated in Figure 7k,1, respectively. It confines that there is no cross interference of frequencies across the loads, i.e., the fundamental frequencies of load 1 is $20 \mathrm{kHz}$ and load 2 is $33 \mathrm{kHz}$. The simulation outcomes are in accordance with the experimental results. 

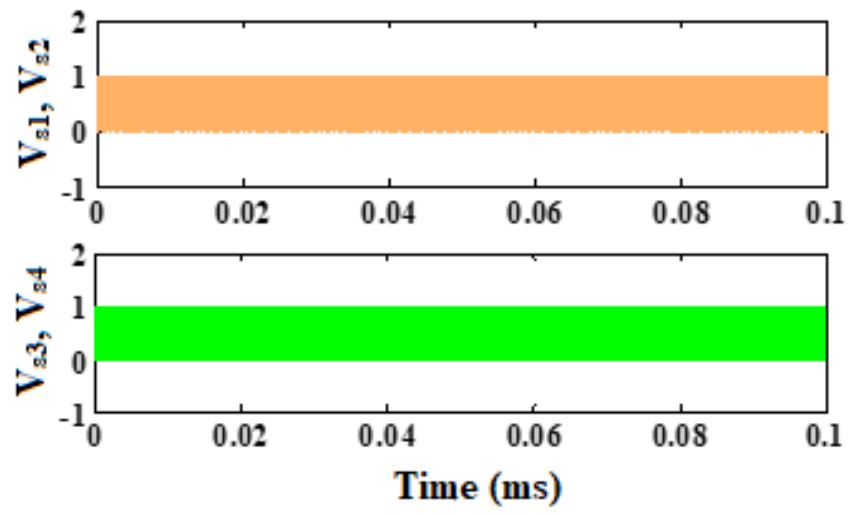

(a)
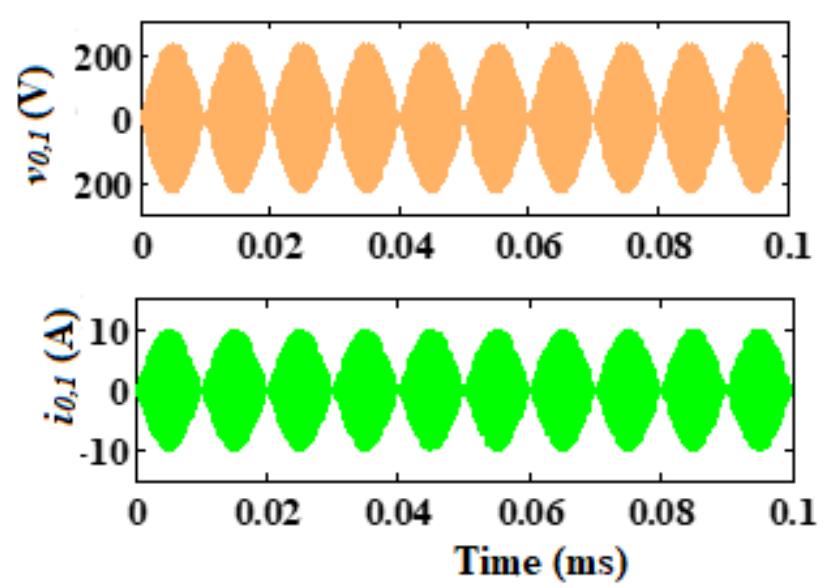

(b)
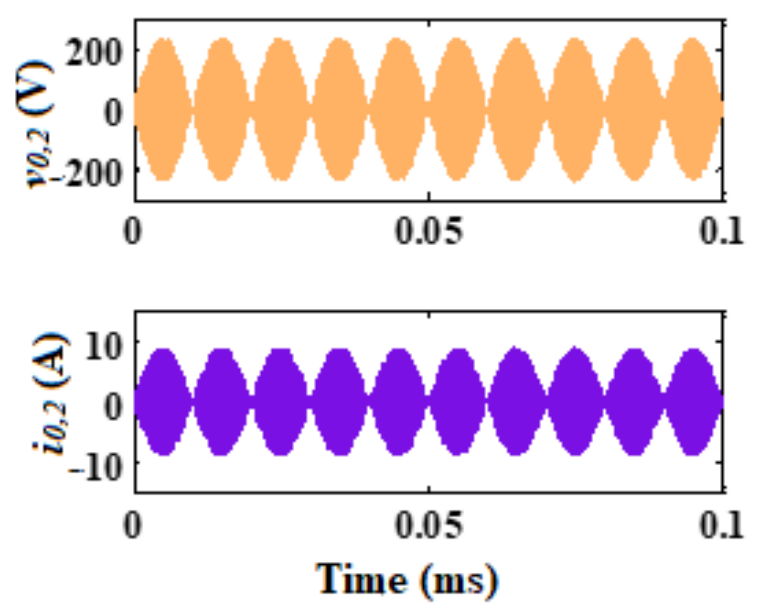

(c)

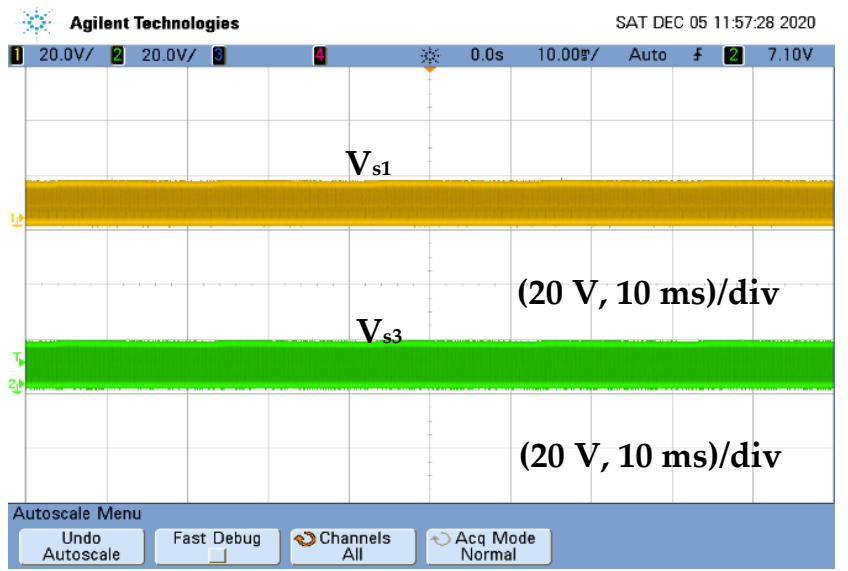

(f)

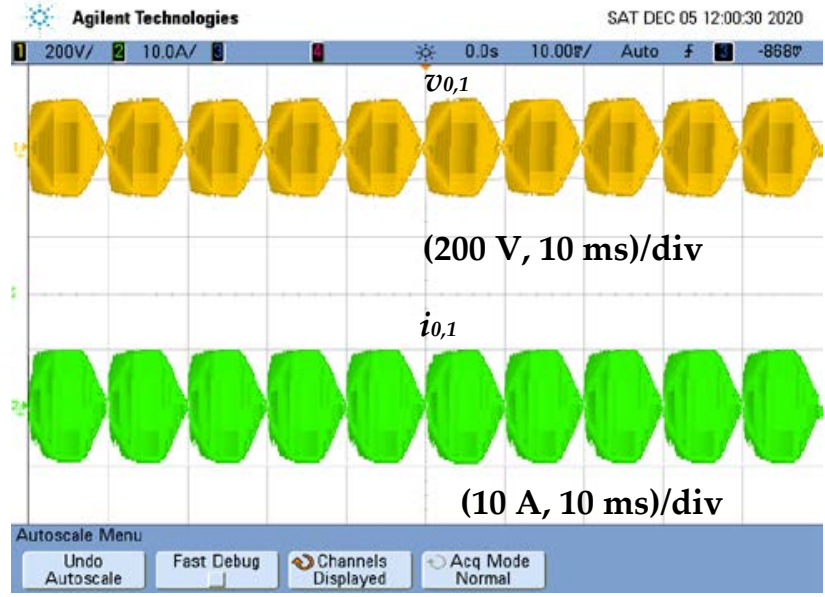

(g)

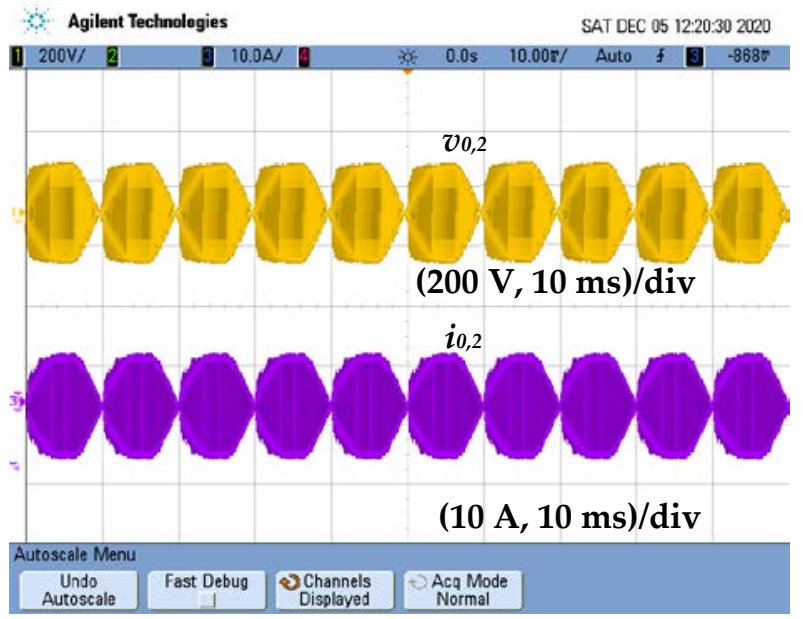

(h)

Figure 7. Cont. 

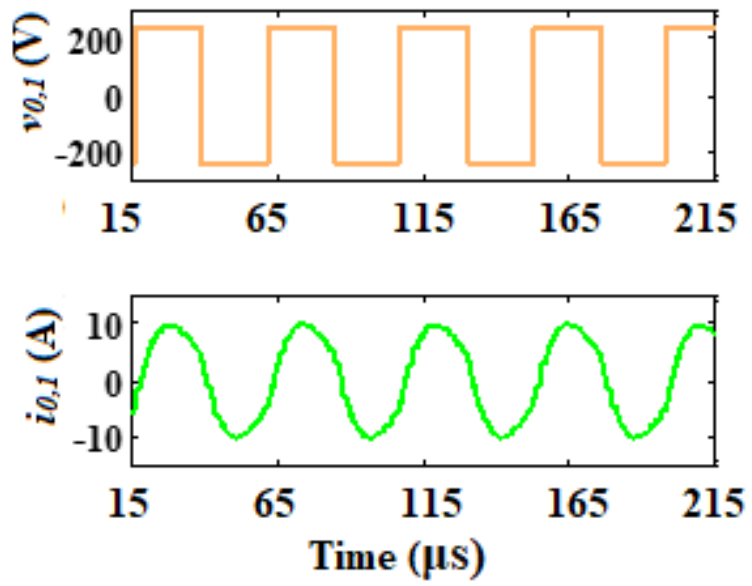

(d)
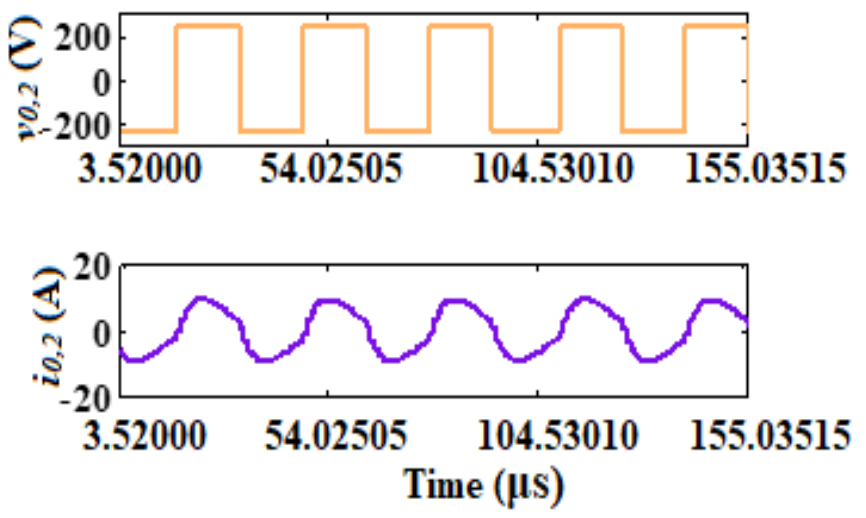

(e)

\begin{tabular}{|c|c|c|c|c|c|c|c|}
\hline \multicolumn{8}{|c|}{ Harmonics } \\
\hline $\begin{array}{l}\text { THD-F } \\
\text { THD-R } \\
\text { RMS }\end{array}$ & $\begin{array}{r}8.9 \% \\
55.8 \% \\
7.09 \mathrm{~A}\end{array}$ & & & & & & \\
\hline 1 & $\sqrt{2} \overline{3}$ & 4 & 5 & 6 & 7 & $8 \longdiv { 9 }$ & $\overline{10}$ \\
\hline & $\begin{array}{l}\text { Freq } \\
(\mathrm{Hz})\end{array}$ & & $\begin{array}{l}\text { Mag } \\
(\%)\end{array}$ & & $\begin{array}{l}\text { Mag } \\
\text { RMS } \\
\text { (V) }\end{array}$ & & $\begin{array}{l}\text { Phase } \\
\left({ }^{\circ}\right)\end{array}$ \\
\hline 1 & $20.01 \mathrm{k}$ & & 100 & & & 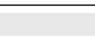 & 0.000 \\
\hline
\end{tabular}

(k)

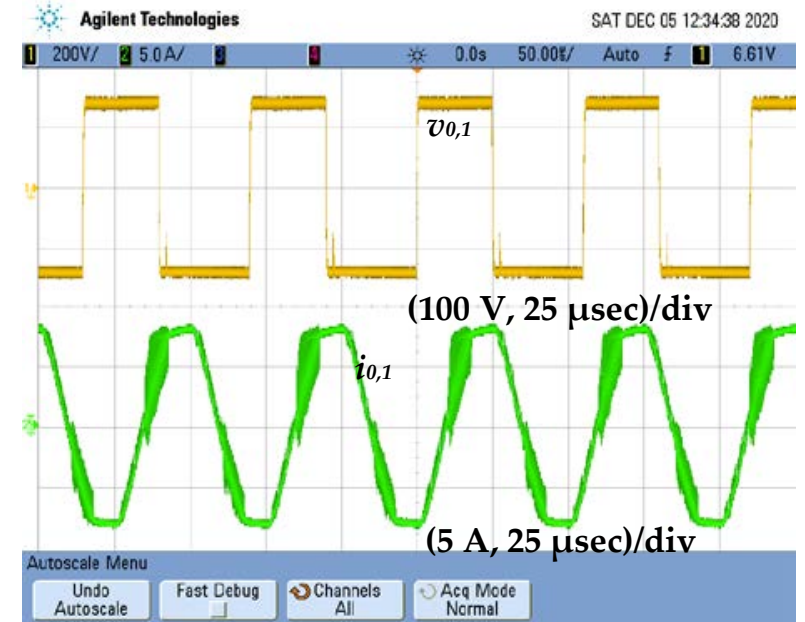

(i)
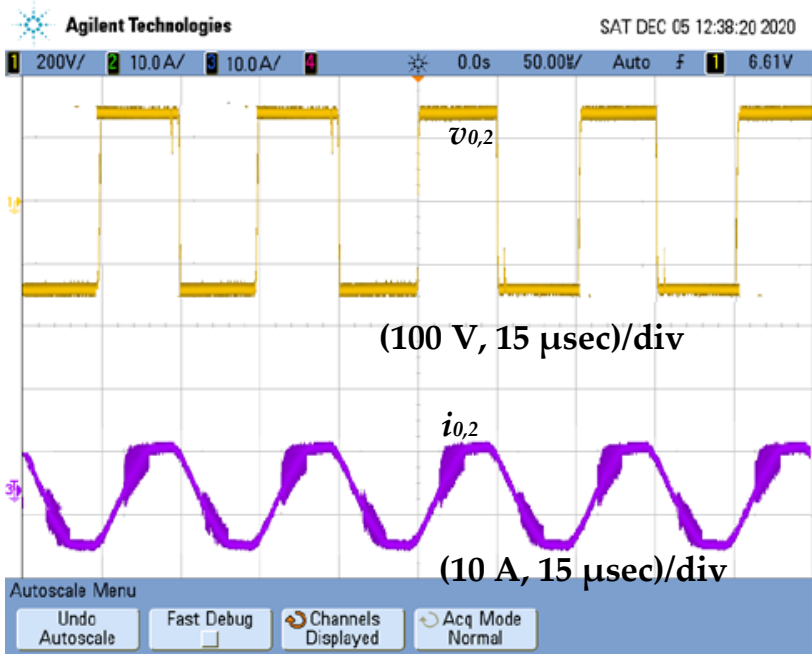

(j)

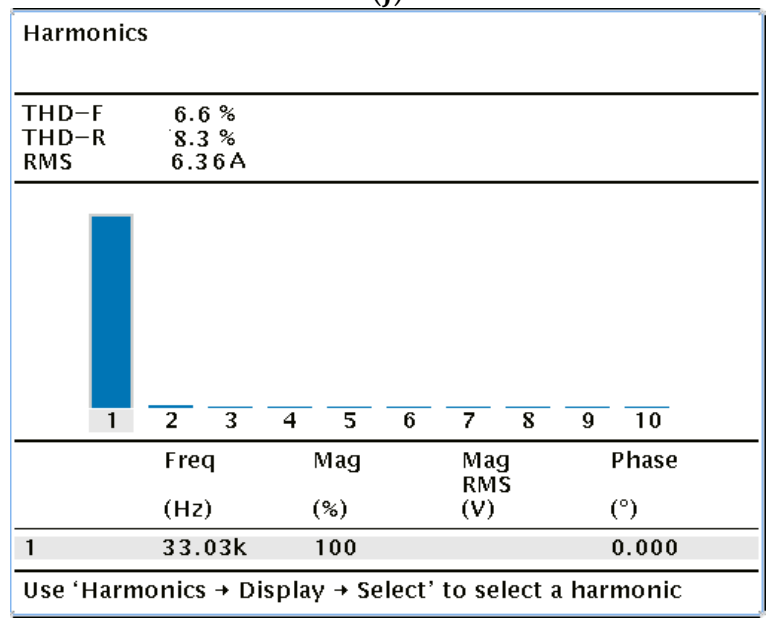

(1)

Figure 7. Main waveforms for $100 \% \mathrm{D}_{\mathrm{PDM}}$ : simulation waveforms (a) switching pulses, (b) output voltage and current of load 1, (c) output voltage current of load 2, (d) zoomed view of the output voltage current of load 1, (e) zoomed view of the output voltage current of load 2, experimental waveforms (f) switching pulses, (g) output voltage and current of load 1 , (h) output voltage current of load 2, (i) zoomed view of the output voltage current of load 1, (j) zoomed view of the output voltage current of load 2, (k) current spectrum of load 1, (1) current spectrum of load 2. 


\subsection{PDM Based Dual Output Power Control for Induction Heating Load}

A smooth and accurate power control technique is required in the IH system to vary the temperature as per the load requirement. PDM-based control logic is used to vary the output power for a single-stage AC-AC converter-fed induction cooking system. The PDM pulses are generated in such a manner that, during the turn-on period of low frequency pulses $\left(\mathrm{T}_{\mathrm{D}, \mathrm{on}}\right)$, high frequency pulses are applied to inverter switches and masked during the turn-off period. The duty cycle of PDM signal ( $D_{\text {PDM }}$ ) with total period $T_{D P D M}$ is

$$
\mathrm{D}_{\mathrm{PDM}}=\frac{\mathrm{T}_{\mathrm{D}, \mathrm{on}}}{\mathrm{T}_{\mathrm{DPDM}}}
$$

The relationship between the rated power $\left(\mathrm{P}_{\text {rated }}\right)$ and the output power $\left(\mathrm{P}_{0}\right)$ with $\mathrm{D}_{\text {PDM }}$ is

$$
\mathrm{P}_{0}=\mathrm{D}_{\mathrm{PDM}} \mathrm{P}_{\text {rated }}
$$

To have control over the output power, an inverter is operated with various $\mathrm{D}_{\mathrm{PDM}}$. As per specifications, load 1 is designed to handle $550 \mathrm{~W}$ and load 2 is designed to handle $445 \mathrm{~W}$ with $\mathrm{R}_{\mathrm{eq}}=11 \Omega$. With $50 \%$ of the $\mathrm{D}_{\mathrm{PDM}}$, the output power is $275 \mathrm{~W}$ for load 1 and $223 \mathrm{~W}$ for load 2. The corresponding waveforms are illustrated in Figure 8. The simulation waveforms of the switching pulses for the inverter are shown in Figure 8a. The corresponding output voltage and current waveforms of load 1 and load 2 are shown in Figure 8b,c, respectively. Experimental switching pulses are shown in Figure 8d and its corresponding voltage and current waveform of load 1 and load 2 is illustrated in Figure 8e,f, respectively. It is inferred from the results that the net power developed in load 1 is reduced to $275 \mathrm{~W}$ and load 2 is reduced to $222.5 \mathrm{~W}$ with $50 \%$ DPDM. The output power is reduced due to the dead band in the output voltage and current. When the inverter's switching pulses are switched off due to the system time constants, the instantaneous current is not zero.

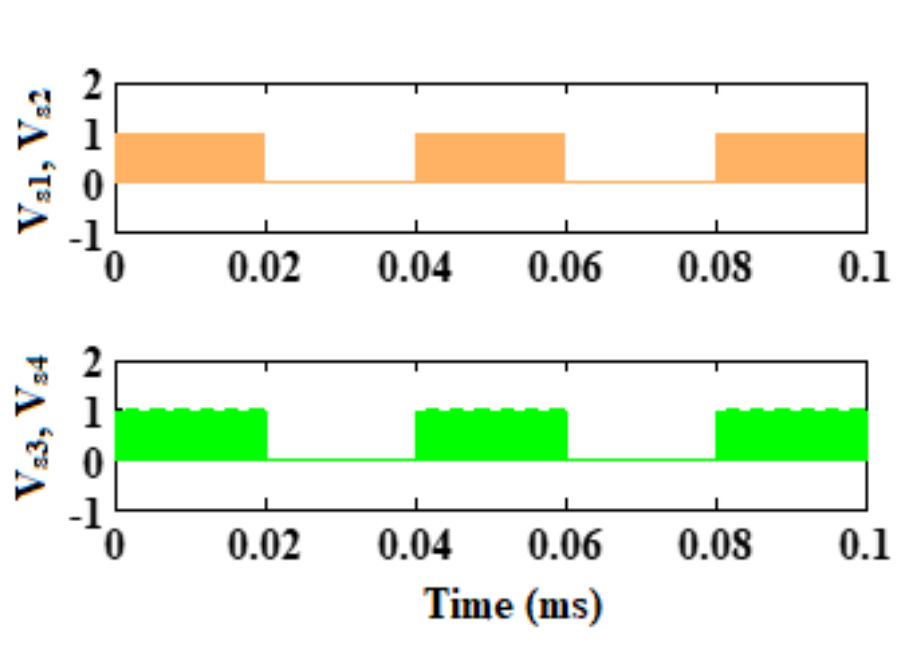

(a)

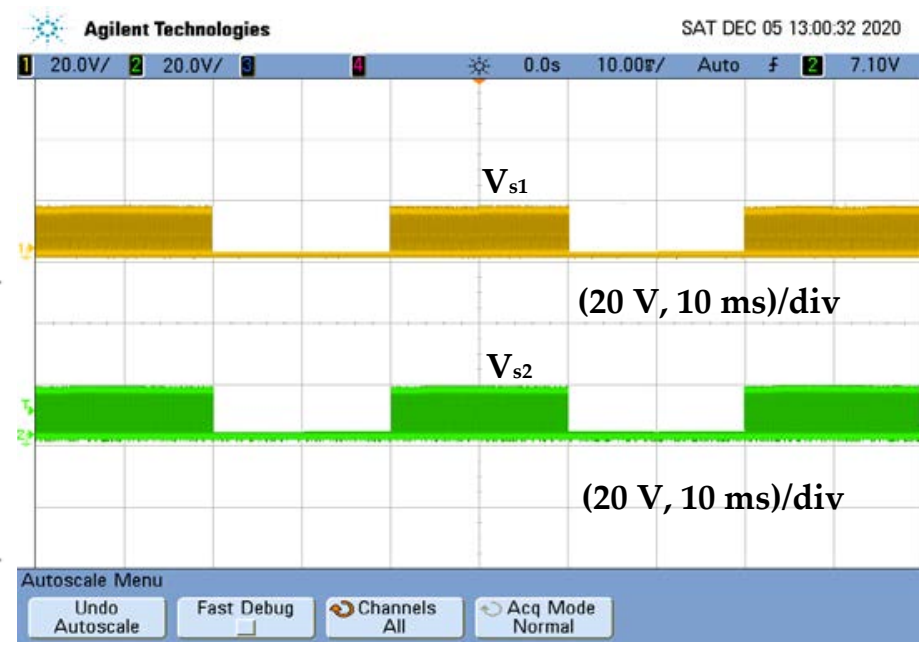

(d)

Figure 8. Cont. 

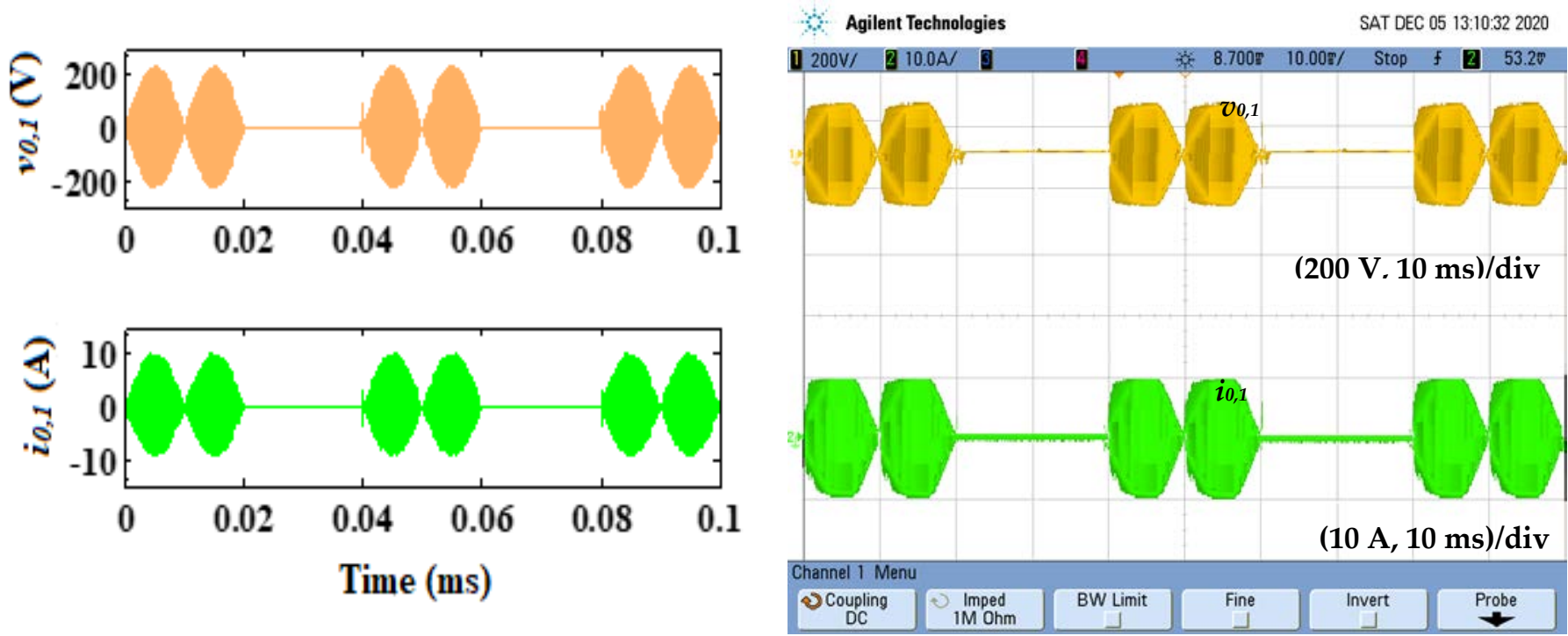

(e)

(b)

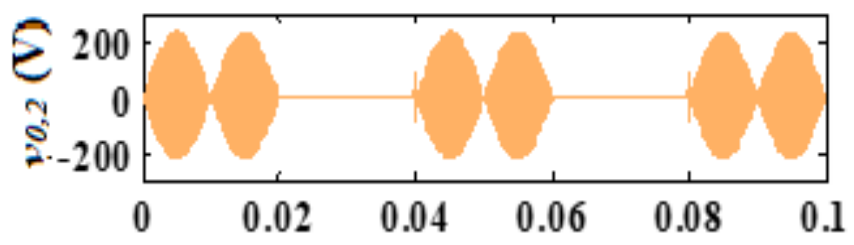

a Agilent Technologies

SAT DEC 05 13:16:32 2020

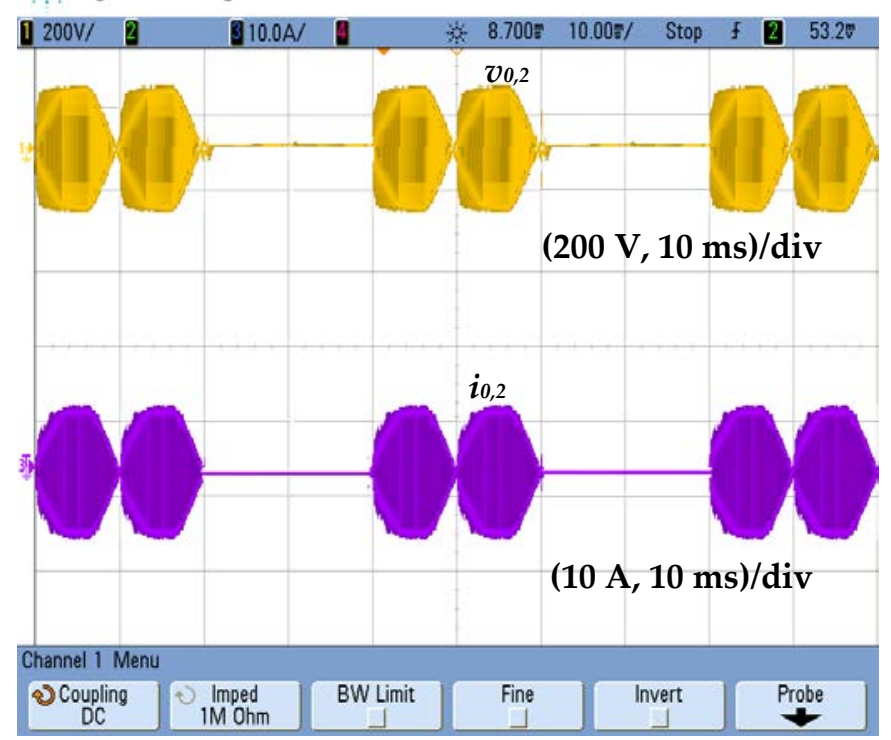

(c)

(f)

Figure 8. Main waveforms for 50\% $\mathrm{D}_{\mathrm{PDM}}$ : simulation waveforms (a) switching pulses, (b) output voltage and current of load 1, (c) output voltage and current of load 2, experimental waveforms (d) switching pulses, (e) output voltage and current of load 1, (f) output voltage and current of load 2.

As the set power is varied from $550 \mathrm{~W}$ to $412.5 \mathrm{~W}$ in load 1 and from $445 \mathrm{~W}$ to $334 \mathrm{~W}$ in load 2, the controller generates the pulses with $75 \% \mathrm{D}_{\mathrm{PDM}}$ to achieve the set power, and its corresponding simulated switching pulses are shown in Figure 9a. The simulated output voltage and current waveforms corresponding to $75 \%$ DPDM of load 1 and load 2 are shown in Figure 9b,c, respectively. As the set power is varied, the DPDM of the inverter is adjusted to obtain the desired output power. The same has been tested in real time and experimental results are validated. Figure $9 \mathrm{~d}$ illustrates the switching pulses of the inverter. The experimental output voltage and current waveforms of load 1 and load 2 are shown in Figure 9e,f, respectively. The efficiency of various $\mathrm{D}_{\mathrm{PDM}}$ is tabulated in Table 3 and it is inferred that the minimum efficiency of the system is $92 \%$ at $5 \% D_{\mathrm{PDM}}$. 

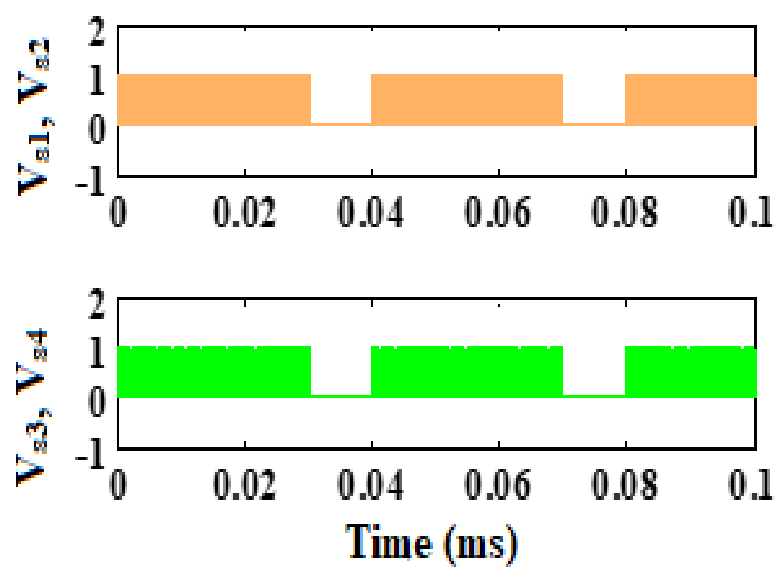

(a)
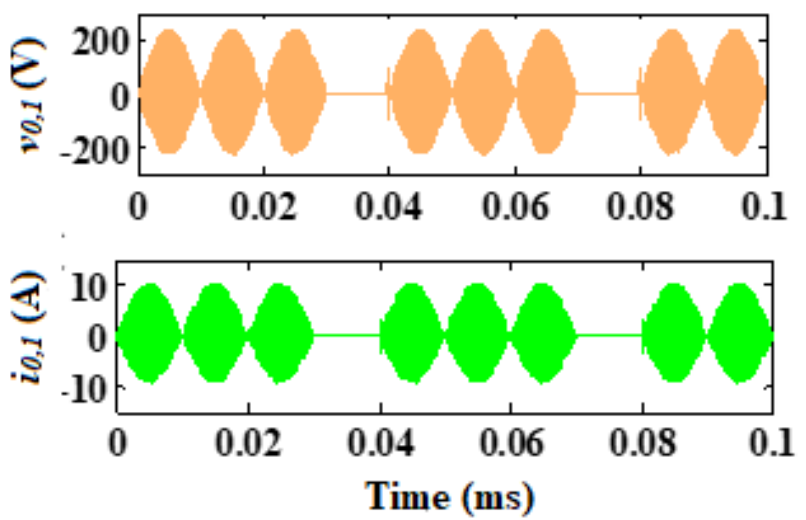

(b)
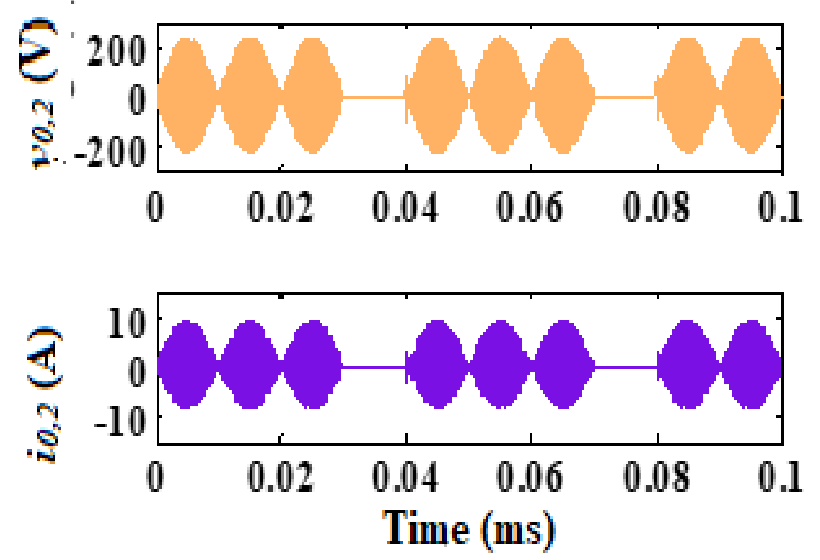

(c)
Agilent Technologies

SAT DEC 05 13:26:29 2020

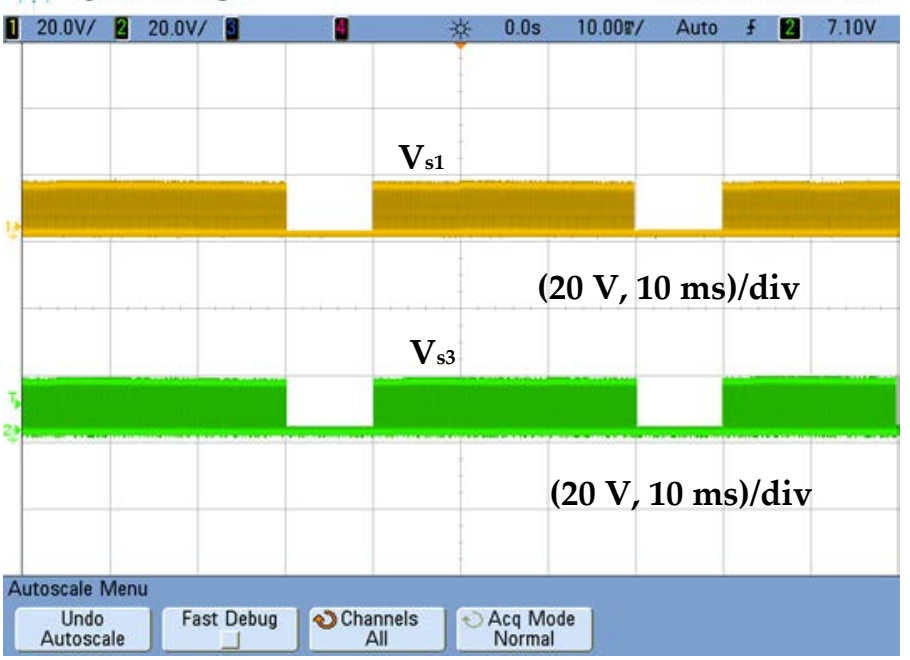

(d)

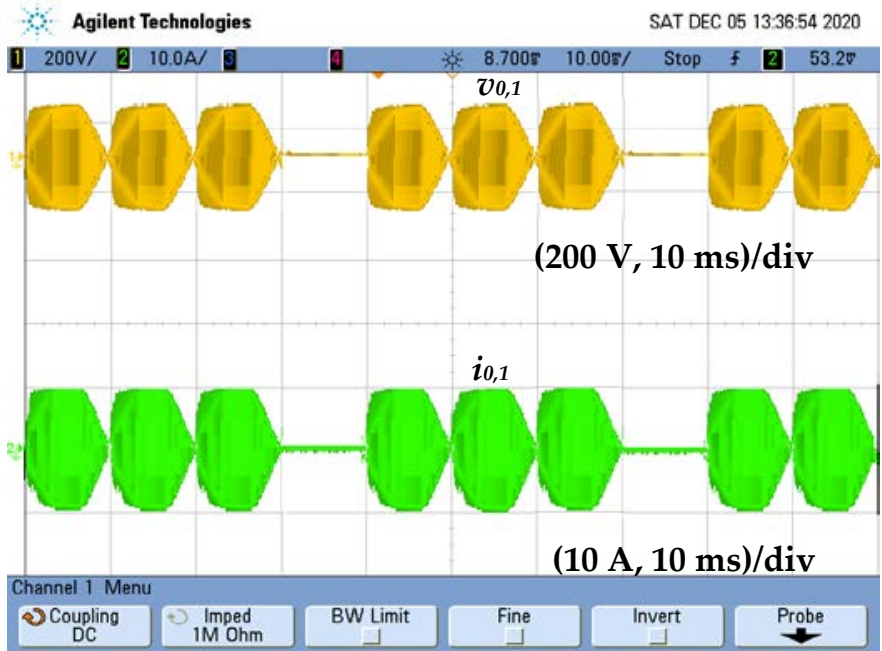

(e)

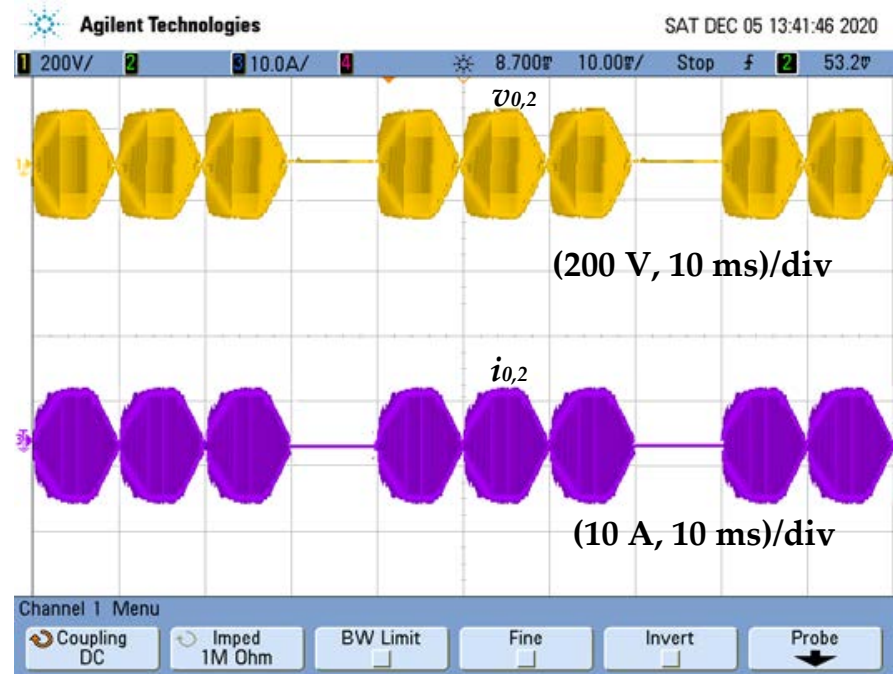

(f)

Figure 9. Main waveforms for 75\% $\mathrm{D}_{\mathrm{PDM}}$ : simulation waveforms (a) switching pulses, (b) output voltage and current of load 1, (c) output voltage and current of load 2, experimental waveforms (d) switching pulses, (e) output voltage and current of load 1, (f) output voltage and current of load 2. 
Table 3. Efficiency for various D PDM.

\begin{tabular}{|c|c|c|c|c|c|c|c|c|c|}
\hline \multirow{2}{*}{ S.No } & \multicolumn{2}{|c|}{$\mathrm{D}_{\mathrm{PDM}}(\%)$} & \multirow{2}{*}{$P_{\text {in }}(W)$} & \multicolumn{2}{|c|}{ Load 1} & \multicolumn{2}{|c|}{ Load 2} & \multirow{2}{*}{$P_{0}(W)$} & \multirow{2}{*}{$\begin{array}{c}\text { Efficiency } \\
(\%)\end{array}$} \\
\hline & Load 1 & Load 2 & & $\mathrm{I}_{01 \mathrm{rms}}(\mathrm{A})$ & $P_{01}(W)$ & $\mathrm{I}_{02 \mathrm{rms}}(\mathrm{A})$ & $P_{02}(W)$ & & \\
\hline 1 & 100 & 100 & 1050.69 & 7.07 & 550 & 6.36 & 445 & 995 & 94.7 \\
\hline 2 & 80 & 80 & 850.43 & 6.32 & 440 & 5.69 & 356 & 796 & 93.6 \\
\hline 3 & 60 & 60 & 640.56 & 5.48 & 330 & 4.93 & 267 & 597 & 93.2 \\
\hline 4 & 45 & 45 & 483.01 & 4.74 & 247.5 & 4.27 & 200.25 & 447.75 & 92.7 \\
\hline 5 & 25 & 25 & 269.21 & 3.54 & 137.5 & 3.18 & 111.25 & 248.75 & 92.4 \\
\hline 6 & 5 & 5 & 54.08 & 1.58 & 27.5 & 1.42 & 22.25 & 49.75 & 92 \\
\hline
\end{tabular}

\subsection{Independent Power Control}

During the real-time operation of a multi-load induction cooking system, individual load requires an independent power control, exclusive to the operation of other loads. With respect to this, the PDM control technique ensures the individual power control of different loads [33]. The system is evaluated with the following two scenarios.

(i) Load 1 requires $137.5 \mathrm{~W}$ and load 2 requires $445 \mathrm{~W}$. In this case, the PDM control signal is chosen with $25 \%$ of $\mathrm{D}_{\mathrm{PDM}}$ for $20 \mathrm{kHz}$ switching and $100 \% \mathrm{D}_{\mathrm{PDM}}$ for $33 \mathrm{kHz}$ switching frequency.

(ii) Load 1 requires $275 \mathrm{~W}$ and load 2 requires $356 \mathrm{~W}$. In this case, the PDM control signal is chosen with $50 \%$ of $D_{\text {PDM }}$ for $20 \mathrm{kHz}$ switching and $75 \% D_{\text {PDM }}$ for $33 \mathrm{kHz}$ switching frequency.

The simulation and experimental output voltage and current waveforms of $25 \% \mathrm{D}_{\mathrm{PDM}}$ for load 1 and 100\% DPDM for load 2 are shown in Figure 10a,b, respectively. From the results, it is concluded that the discontinuous current of load 1 results in a reduction in output power without disturbing load 2. Similarly, for scenario 2, the output voltage and current waveforms of load 1 and load 2 for $50 \%$ DPDM for load 1 and $75 \% D_{\text {PDM }}$ for load 2 are shown in Figure 10c,d. It confirms that the developed system is good enough to handle both the loads with two different power setting. The efficiency of the IH system for different $\mathrm{D}_{\text {PDM }}$ values is shown in Table 4 . The control scheme can facilitate power control to multi-load applications with reduced physical components. Additionally, it has the unique advantage of achieving independent power control with higher efficiency, ensuring constant frequency operation. Moreover, the control scheme can make the inverter operate at ZVS for a wide range of power control.

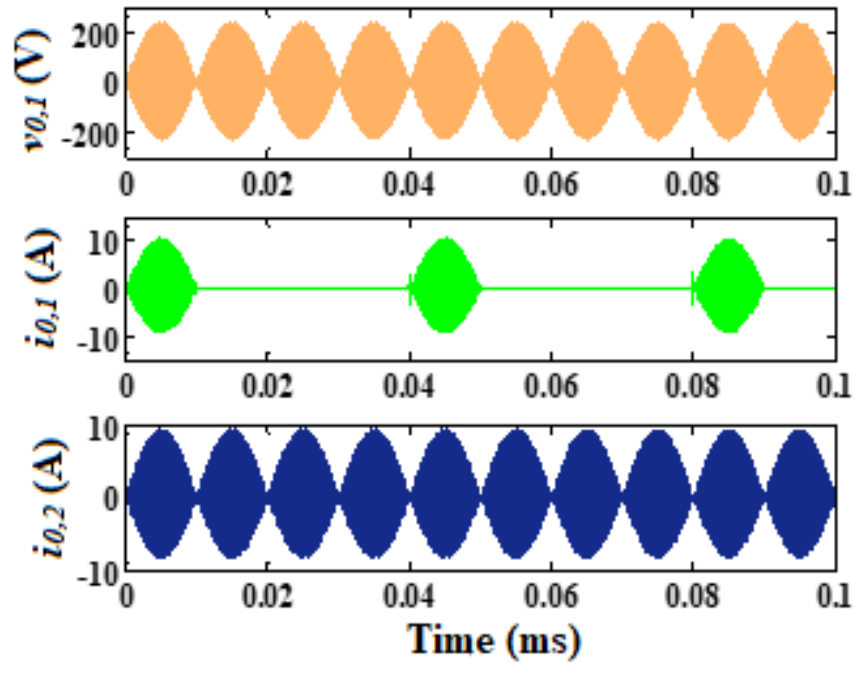

(a)

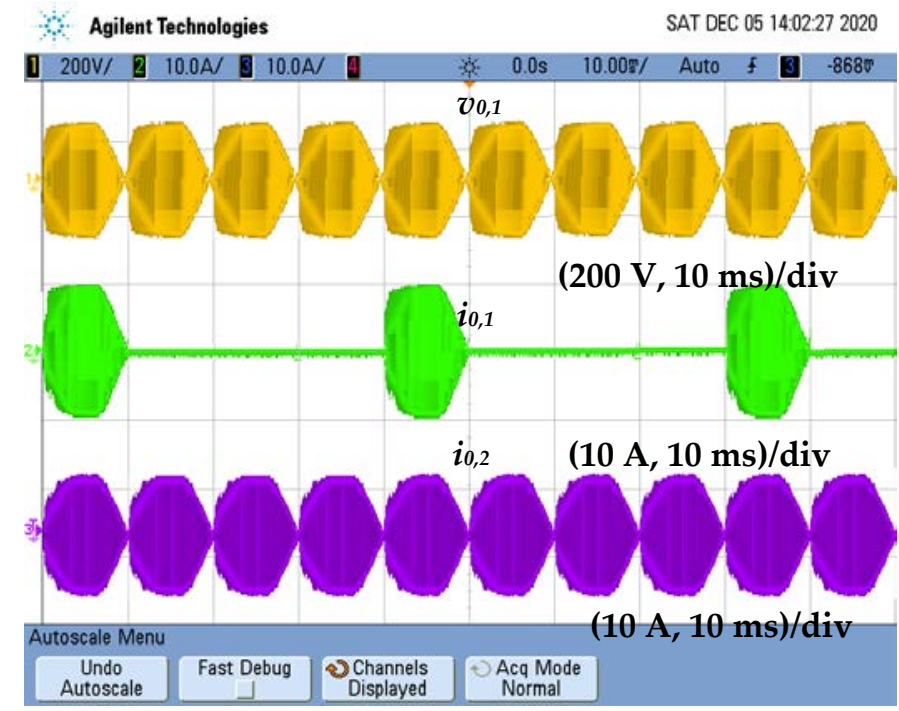

(b)

Figure 10. Cont. 

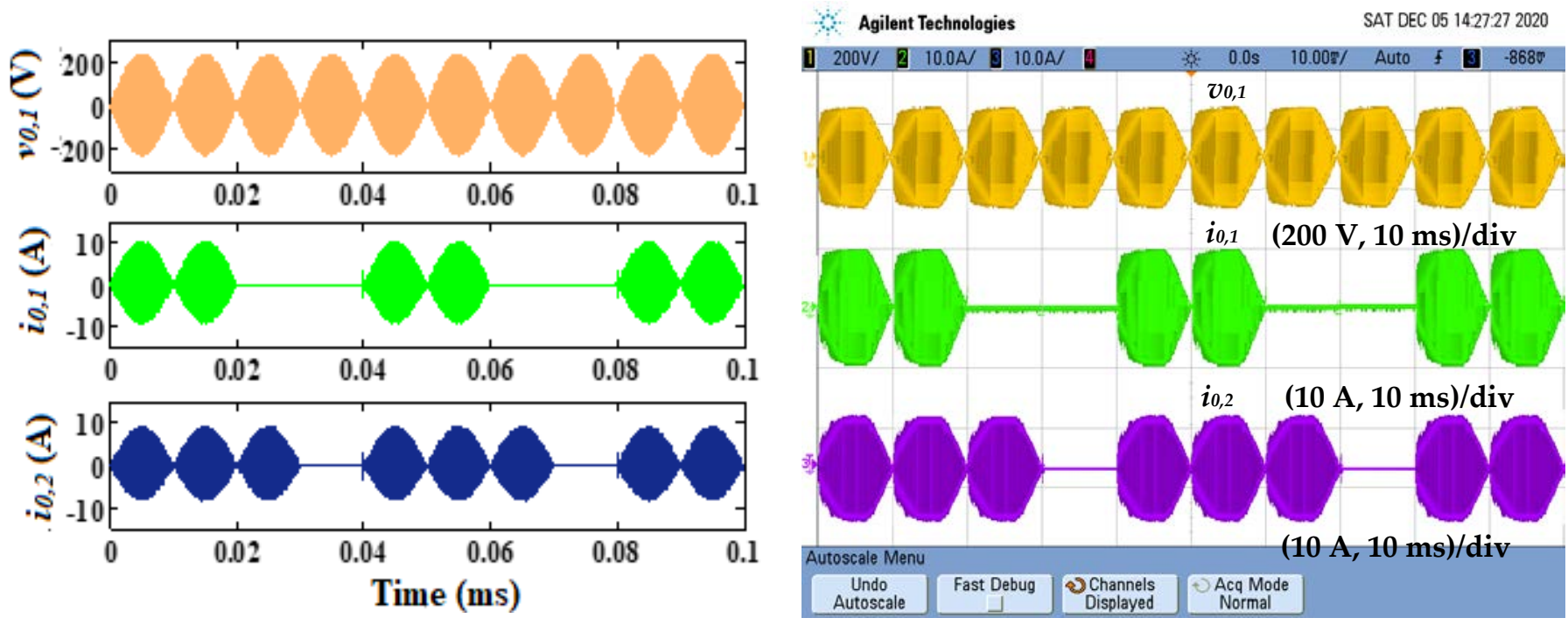

(c)

(d)

Figure 10. Voltage and currents waveform of $25 \% \mathrm{D}_{\mathrm{PDM}}$ for load 1 and $100 \% \mathrm{D}_{\mathrm{PDM}}$ for load 2 (a) simulation, (b) hardware, voltage and currents waveform of 50\% DPDM for load 1 and 75\% DPDM for load 2 (c) simulation, (d) hardware.

Table 4. Efficiency of the IH system with independent control.

\begin{tabular}{|c|c|c|c|c|c|c|c|c|c|}
\hline \multirow{2}{*}{ S.No } & \multicolumn{2}{|c|}{$\mathrm{D}_{\mathrm{PDM}}(\%)$} & \multirow{2}{*}{$P_{\text {in }}(W)$} & \multicolumn{2}{|c|}{ Load 1} & \multicolumn{2}{|c|}{ Load 2} & \multirow{2}{*}{$P_{0}(W)$} & \multirow{2}{*}{ Efficiency (\%) } \\
\hline & Load 1 & Load 2 & & $\mathrm{I}_{01 \mathrm{rms}}(\mathrm{A})$ & $P_{01}(W)$ & $\mathrm{I}_{02 \mathrm{rms}}(\mathrm{A})$ & $P_{02}(W)$ & & \\
\hline 1 & 100 & 80 & 966.92 & 7.07 & 550 & 5.69 & 356 & 906 & 93.7 \\
\hline 2 & 100 & 50 & 825.67 & 7.07 & 550 & 4.50 & 222.5 & 772.5 & 93.56 \\
\hline 3 & 100 & 10 & 637.33 & 7.07 & 550 & 2.01 & 44.5 & 594.5 & 93.28 \\
\hline 4 & 85 & 100 & 974.37 & 6.52 & 467.5 & 6.36 & 445 & 912.5 & 93.65 \\
\hline 5 & 45 & 100 & 741.28 & 4.74 & 247.5 & 6.36 & 445 & 692.5 & 93.42 \\
\hline 6 & 10 & 100 & 539.08 & 2.24 & 55 & 6.36 & 445 & 500 & 92.75 \\
\hline
\end{tabular}

\subsection{Thermal Analysis of Load}

In the COMSOL environment, the traditional IH structure is modelled on a 2-dimensional, axis-symmetrical, with 28-turns work coil, each of $3 \mathrm{~mm}$ diameter. The average diameter of the operating coil is $128 \mathrm{~mm}$ and the vessel carrying water is considered as a load. The system is solved by means of a magnetic field heat transfer solver in solid physics to achieve transient frequency solutions. Input parameters for transient frequency analysis include the geometry of the IH system, the magnetic properties of the load, the frequency and the output of the current. Using magnetic and heat transfer physics, COMSOL estimates the heat which develops on the load. As a user-defined equation in COMSOL, the switching frequency and current flowing through each load is evaluated and fed as input. The rate of heat generation on the work piece is estimated using the thermal conductance model of the IH system for various intervals. In this model, the surface-to-ambient heat radiation boundary conditions are used on all the external surfaces for performing the temperature analysis. The geometry is messed into 10,254 triangular elements for solving the system. The FLIR E75 $24^{\circ}$ advanced thermal imager is used to capture the load thermal image. The simulated and experimental temperature profiles for load 1 and load 2 are shown in Figure $11 \mathrm{a}-\mathrm{d}$. The thermal rise is recorded at time $t=180 \mathrm{~s}$ for both the loads, and it is observed that the highest temperature difference is $16 \%$, as the power difference between the two loads is $19 \%$. It implies that the produced temperature and power developed on the load are directly proportional with each other. The overall thermal image of the multi-load fed IH system is shown in Figure 9e.

The increase in temperature at different instants is shown in Figure 12. It is found that at $t=180 \mathrm{~s}$, the heat developed in load 1 is $79{ }^{\circ} \mathrm{C}$ and in load 2 is $66.5^{\circ} \mathrm{C}$. It is inferred that 
the temperature increases with respect to time for both the loads. Similarly, the variation of temperature with respect to $\mathrm{D}_{\mathrm{PDM}}$ is shown in Figure 13. From the response, it is concluded that the temperature is varied by adjusting the D PDM. The total modular power loss for various $\mathrm{D}_{\mathrm{PDM}}$ with existing topology is shown in Figure 14. It is inferred that the proposed system possesses minimum losses for the variation in $\mathrm{D}_{\mathrm{PDM}}$.

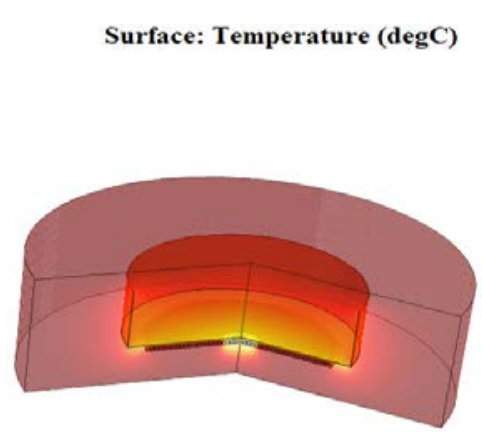

(a)

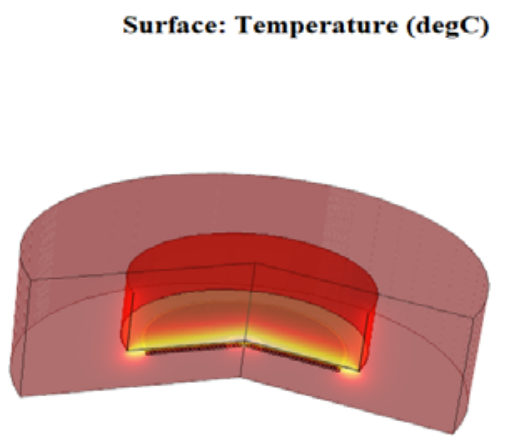

(b)
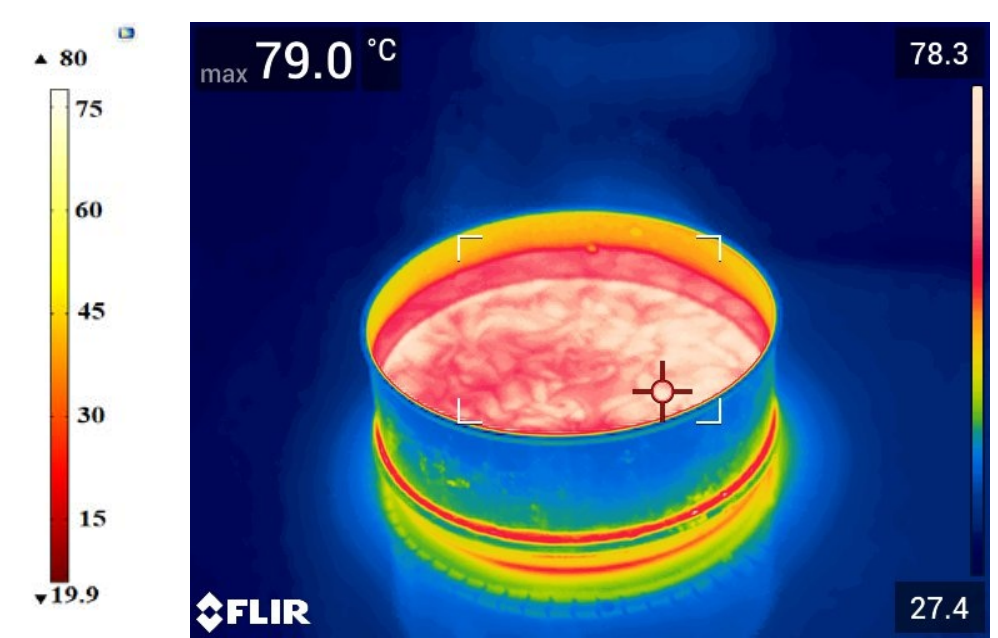

(c)

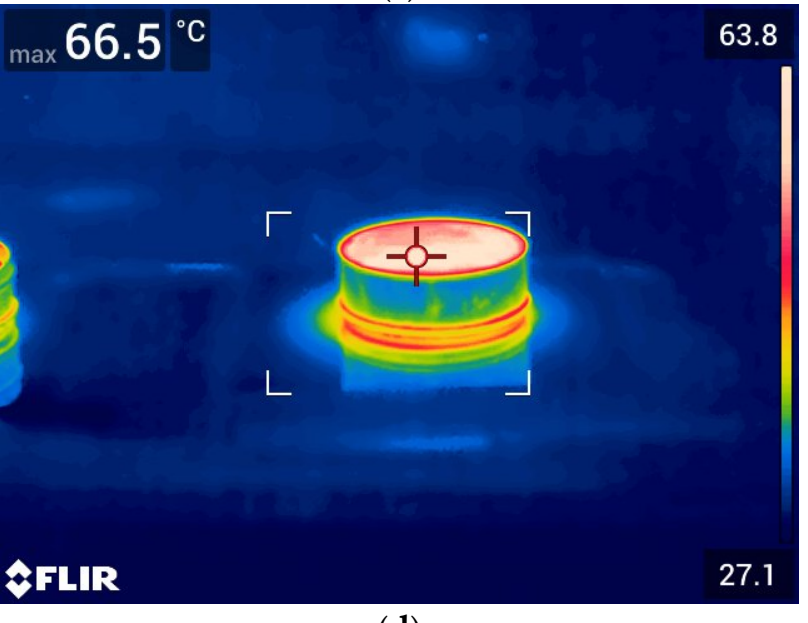

(d)

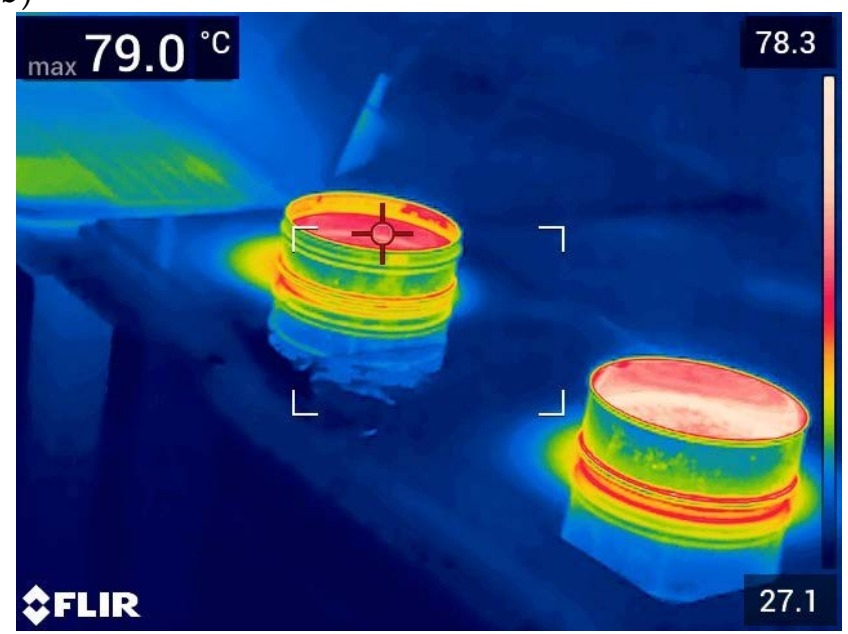

(e)

Figure 11. Simulated thermal image of (a) load 1 (b) load 2; experimental thermal image of (c) load 1, (d) load 2, (e) load 1 and load 2. 


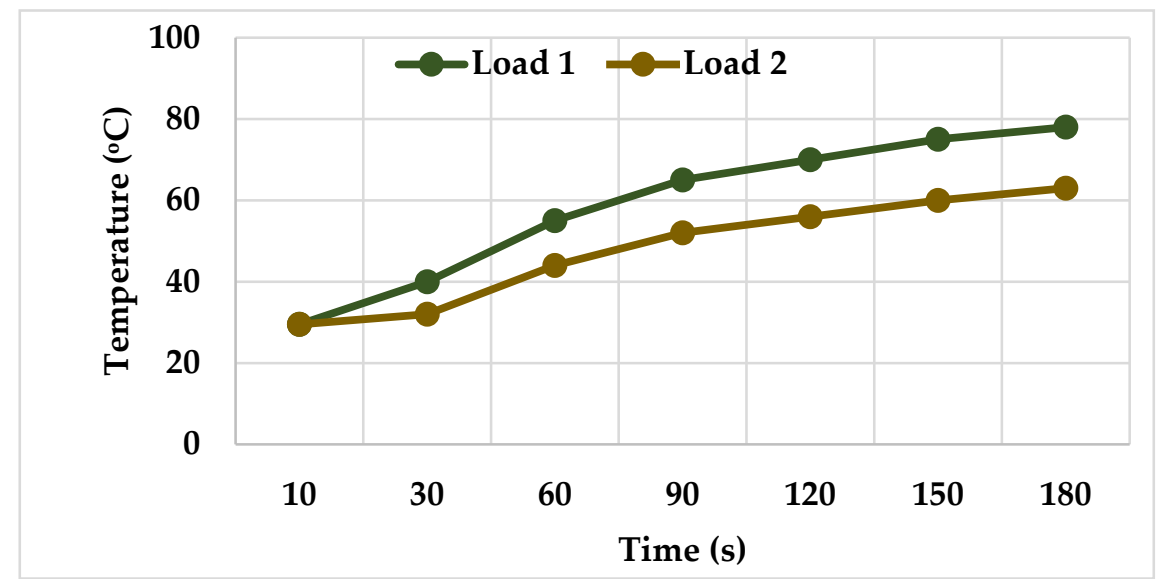

Figure 12. Variations of temperature with respect to time.

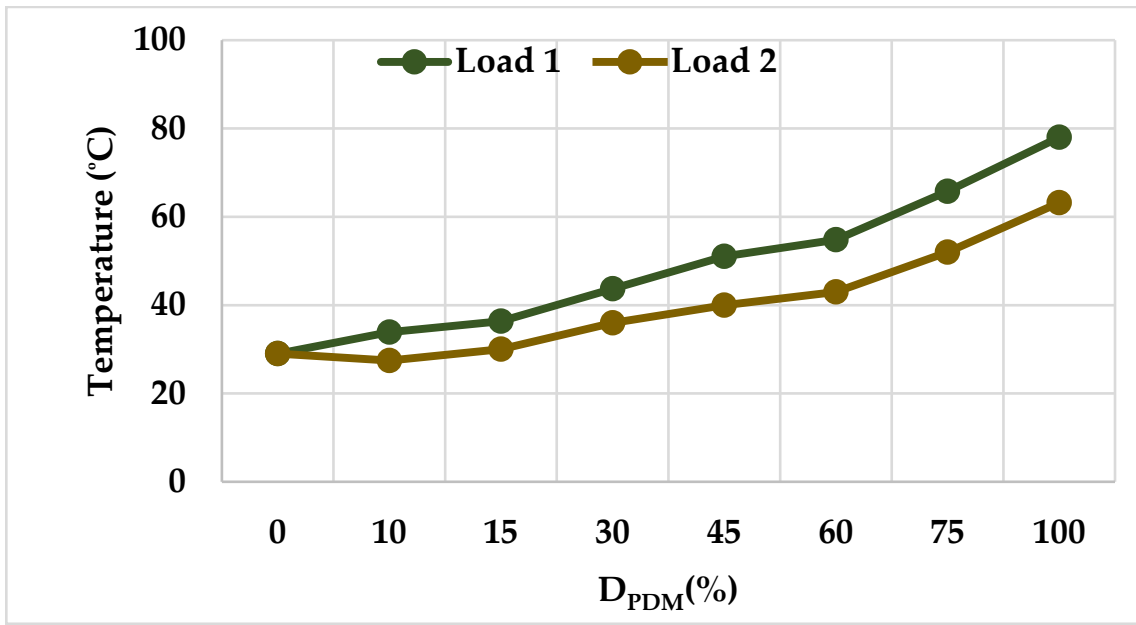

Figure 13. Variations of temperature with respect to $\mathrm{D}_{\mathrm{PDM}}$.

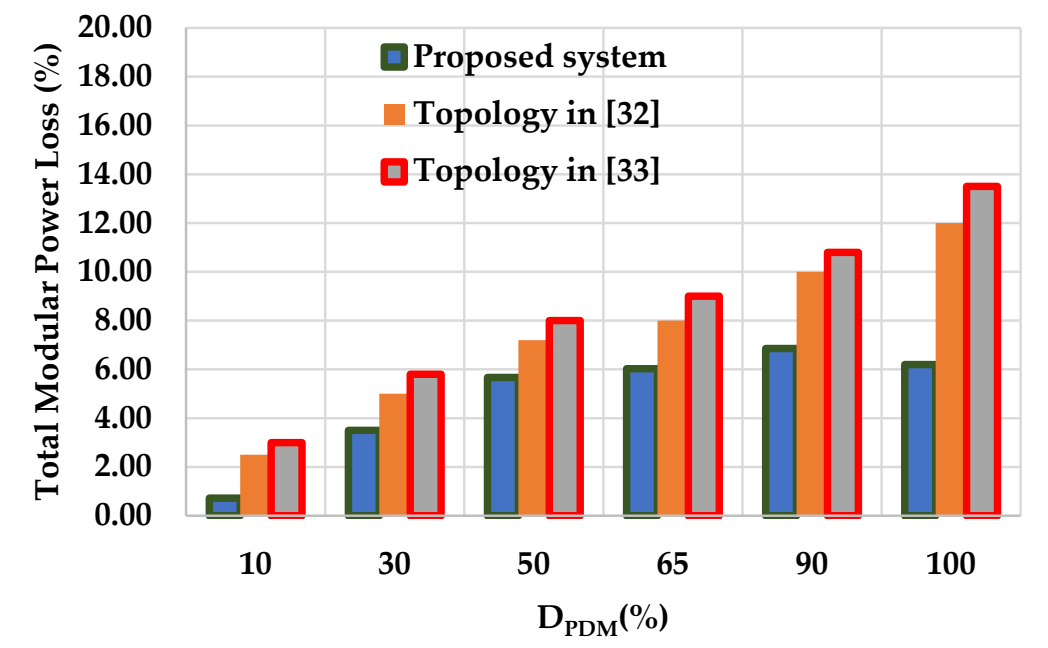

Figure 14. Total modular power loss.

The comparison of the proposed topology with respect to the existing topologies are listed in Table 5. It is inferred that the proposed IH system possesses higher efficiency with the minimum semiconductor switches. The efficiency of the proposed system with respect to the existing topologies is shown in Figure 15. The maximum efficiency occurs at 100\% 
$\mathrm{D}_{\mathrm{PDM}}$. Additionally, for the remaining values of $\mathrm{D}_{\mathrm{PDM}}$, efficiency is greater than $92 \%$. Thus, the proposed control technique can be used for a single/two induction cooking system.

Table 5. Comparison with existing topology.

\begin{tabular}{ccccccccc}
\hline S. No & Ref. No & $\begin{array}{c}\text { Number of } \\
\text { Semiconductor } \\
\text { Switches }\end{array}$ & $\begin{array}{c}\text { Modulation } \\
\text { Technique }\end{array}$ & $\begin{array}{c}\text { Number of } \\
\text { Loads }\end{array}$ & $\begin{array}{c}\text { Flicker } \\
\text { Issue }\end{array}$ & $\begin{array}{c}\text { Soft } \\
\text { Switching }\end{array}$ & $\begin{array}{c}\text { Control } \\
\text { Complexity }\end{array}$ & $\begin{array}{c}\text { Maximum } \\
\text { Efficiency (\%) }\end{array}$ \\
\hline 1 & {$[20]$} & 8 & AVC & 1 & No & Partially & Neutral & 92.5 \\
2 & {$[32]$} & 4 & PDM & 2 & Yes & Partially & Neutral & 93.2 \\
3 & {$[33]$} & 4 & PDM & 1 & Yes & Fully & Good & 93.7 \\
4 & Proposed & 4 & PDM & 2 & No & Fully & Good & 94.7 \\
\hline
\end{tabular}

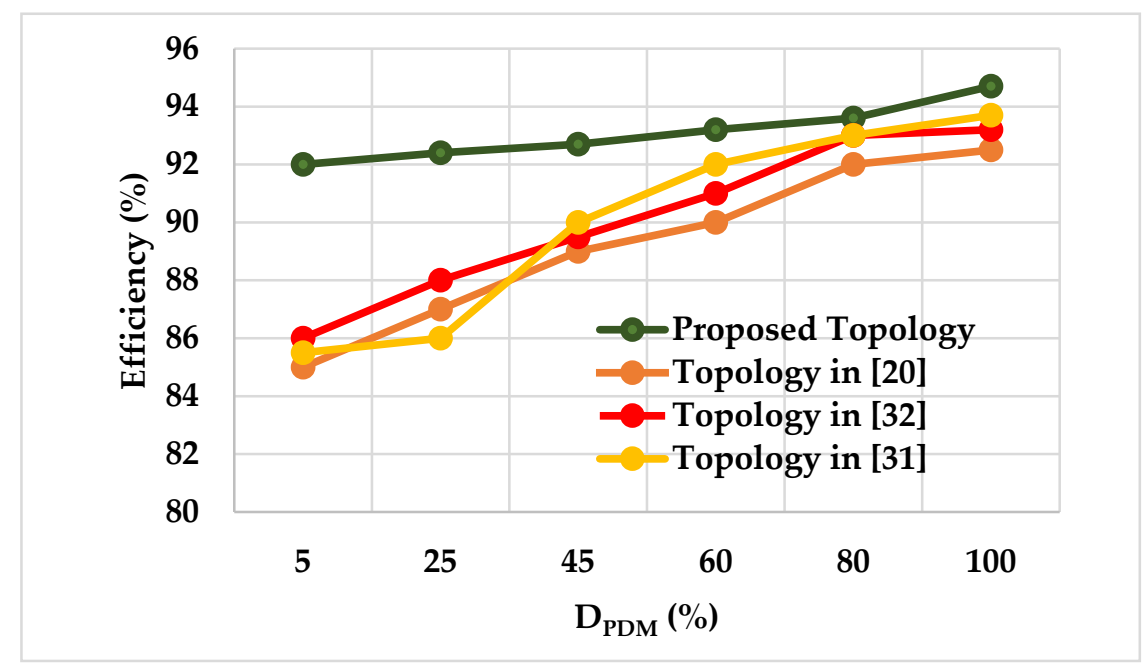

Figure 15. Efficiency variations for distinct load power.

\section{Conclusions}

In this work, a single-stage AC-AC series resonant inverter for a cooking application feeding power to multiple loads is proposed using a single supply frequency. The proposed scheme is tested by placing the transmitter coil and work coil at a distance of $3 \mathrm{~cm}$, which produces the dual frequencies at the output side for a $25 \mathrm{kHz}$ source frequency. The bifurcated frequencies, such as $20 \mathrm{kHz}$ and $33 \mathrm{kHz}$, are used to power load 1 and load 2, respectively. The current spectrum confines that there is no cross-frequency interference across the loads. The output power control is performed by adjusting the duty cycle of the PDM signal. The temperature in both the loads is studied using an FLIR thermal imager for various time instants. The summary of this work is listed as follows:

- Output power is controlled from $100 \%$ to $0 \%$ of the rated power.

- The proposed inverter possesses higher efficiency of about $94.7 \%$ at $100 \% \mathrm{D}_{\mathrm{PDM}}$ and is greater than $92 \%$ for other values of $\mathrm{D}_{\mathrm{PDM}}$.

- Independent power control is achieved.

- The output power can be regulated to any value within the rated power.

- At rated power, the system possesses $5 \%$ less power losses as compared with the existing articles [31,32].

- As switching frequency is not varied, soft switching is realized for the whole operating range.

- The PDM frequency is chosen as $25 \mathrm{~Hz}$, which results in no noise.

From the test results, it can be concluded that the proposed system produces multiple output frequencies with a single source. Though the tested system is able to handle two loads, the power rating cannot be maintained as uniform due to multi-frequency operations. Thus, a converter topology is required to produce uniform power distribution across all loads. This work can be extended for more loads by varying the distance. 
Author Contributions: Conceptualization, P.V. and S.D.; methodology, K.B.; software, S.B.T.; validation, P.V., S.D. and S.B.T.; formal analysis, B.N.; investigation, P.V.; resources, B.N.; data curation, P.V.; writing-original draft preparation, P.V.; writing-review and editing, P.V., S.D., S.B.T., K.B. and B.N; visualization, B.N.; supervision, B.N.; project administration, S.B.T.; funding acquisition, B.N. All authors have read and agreed to the published version of the manuscript.

Funding: This research received no external funding.

Institutional Review Board Statement: Not applicable.

Informed Consent Statement: Not applicable.

Data Availability Statement: Not applicable.

Conflicts of Interest: The authors declare no conflict of interest.

\section{Nomenclature}

$\mathrm{R}_{\mathrm{eq}} \quad$ Equivalent load resistance $(\Omega)$

$\mathrm{L}_{\mathrm{eq}} \quad$ Equivalent load inductance $(\mathrm{H})$

$\mathrm{V}_{\mathrm{ab}} \quad$ Supply voltage (V)

$\mathrm{R}_{\mathrm{p} 1} \quad$ Work coil resistance of load $1(\Omega)$

$\mathrm{R}_{\mathrm{p} 2} \quad$ Work coil resistance of load $2(\Omega)$

$\mathrm{L}_{\mathrm{p} 1} \quad$ Primary inductance of load $1(\mathrm{H})$

$\mathrm{L}_{\mathrm{p} 2} \quad$ Primary inductance of load $2(\mathrm{H})$

$\mathrm{L}_{\mathrm{s} 1} \quad$ Secondary inductance of load $1(\mathrm{H})$

$\mathrm{L}_{\mathrm{s} 2} \quad$ Secondary inductance of load $2(\mathrm{H})$

$\mathrm{V}_{\mathrm{m}} \quad$ Maximum peak value of the input voltage $(\mathrm{V})$

$\theta \quad$ Angle difference between voltage and current (degree)

$\mathrm{M}_{12} \quad$ Mutual inductance of source on load $2(\mathrm{H})$

$\mathrm{M}_{21} \quad$ Mutual inductance of source on load $1(\mathrm{H})$

$\mathrm{Z}_{\mathrm{eq} 1} \quad$ Equivalent impedance of load $1(\Omega)$

$\mathrm{Z}_{\text {eq2 }} \quad$ Equivalent impedance of load $2(\Omega)$

$\eta_{1} \quad$ Efficiency of load 1

$\eta_{2} \quad$ Efficiency of load 2

$\mathrm{v}_{0,1} \quad$ Load 1 voltage $(\mathrm{V})$

$\mathrm{v}_{0,2} \quad$ Load 2 voltage $(\mathrm{V})$

$\mathrm{i}_{0,1} \quad$ Load 1 current $(\mathrm{A})$

$\mathrm{i}_{0,2} \quad$ Load 2 current (A)

$R_{\text {eq1 }} \quad$ Equivalent load resistance of load $1(\Omega)$

$\mathrm{R}_{\mathrm{eq} 2}$ Equivalent load resistance of load $2(\Omega)$

$\mathrm{L}_{\text {eq1 }} \quad$ Equivalent load inductance of load $1(\mathrm{H})$

$\mathrm{L}_{\mathrm{eq} 2} \quad$ Equivalent load inductance of load $2(\mathrm{H})$

$\mathrm{C}_{\mathrm{r} 1} \quad$ Resonant capacitor of load 1 (F)

$\mathrm{C}_{\mathrm{r} 2} \quad$ Resonant capacitor of load $2(\mathrm{~F})$

$\omega_{\mathrm{s}} \quad$ Angular switching frequency ( $\mathrm{rad} / \mathrm{sec}$ )

$\mathrm{L}_{\mathrm{s}} \quad$ Input inductor $(\mathrm{H})$

$\mathrm{R}_{\mathrm{S}} \quad$ Source coil resistance $(\Omega)$

$\mathrm{C}_{\mathrm{S}} \quad$ Source capacitor $(\mathrm{F})$

$\mathrm{P}_{\text {rat }} \quad$ Rated output power $(\mathrm{W})$

$\mathrm{f}_{\mathrm{PDM}}$ PDM switching frequency $(\mathrm{Hz})$

$\mathrm{f}_{\mathrm{r}} \quad$ Resonant frequency $(\mathrm{Hz})$

$\mathrm{f}_{\mathrm{r} 1} \quad$ Resonant frequency of load $1(\mathrm{~Hz})$

$\mathrm{f}_{\mathrm{r} 2} \quad$ Resonant frequency of load $2(\mathrm{~Hz})$

$\omega_{\mathrm{r} 1} \quad$ Angular resonant frequency of load $1(\mathrm{rad} / \mathrm{sec})$

$\omega_{\mathrm{r} 2}$ Angular resonant frequency of load $2(\mathrm{rad} / \mathrm{sec})$

$\mathrm{d}_{12} \quad$ Distance between source and load $1(\mathrm{~cm})$

$\mathrm{d}_{13} \quad$ Distance between source and load $2(\mathrm{~cm})$ 


\section{References}

1. Acero, J.A.; Burdio, J.M.; Barragan, L.A.; Navarro, D.; Alonso, R.M.; Garcia, J.R.; Monterde, F.; Hernandez, P.; Llorente, S.; Garde, I. The domestic induction heating appliance: An overview of recent research. In Proceedings of the 2008 Twenty-Third Annual IEEE Applied Power Electronics Conference and Exposition, Austin, TX, USA, 24-28 February 2008; Volume 16, pp. 651-657. [CrossRef]

2. Park, S.M.; Jang, E.; Joo, D.; Lee, B.K. Power Curve-Fitting Control Method with Temperature Compensation and Fast-Response for All-Metal Domestic Induction Heating Systems. Energies 2019, 12, 2915. [CrossRef]

3. Yilmaz, I.; Ermis, M.; Cadirci, I.; Yılmaz, I. Medium frequency induction melting furnace as a load on the power system. In Proceedings of the 2011 IEEE Industry Applications Society Annual Meeting, Orlando, FL, USA, 9-13 October 2011; Volume 48, pp. 1-12. [CrossRef]

4. Egalon, J.; Caux, S.; Maussion, P.; Souley, M.; Pateau, O. Multiphase System for Metal Disc Induction Heating: Modeling and RMS Current Control. IEEE Trans. Ind. Appl. 2012, 48, 1692-1699. [CrossRef]

5. Millán, I.; Burdío, J.; Acero, J.A.; Lucía, O.; Llorente, S. Series resonant inverter with selective harmonic operation applied to all-metal domestic induction heating. IET Power Electron. 2011, 4, 587. [CrossRef]

6. Lucía, O.; Burdío, J.M.; Millán, I.; Acero, J.; Barragán, L.A. Efficiency-Oriented Design of ZVS Half-Bridge Series Resonant Inverter With Variable Frequency Duty Cycle Control. IEEE Trans. Power Electron. 2010, 25, 1671-1674. [CrossRef]

7. Sarnago, H.; Lucía, Ó.; Pérez-Tarragona, M.; Burdío, J.M. Dual-Output Boost Resonant Full-Bridge Topology and its Modu-lation Strategies for High-Performance Induction Heating Applications. IEEE Trans. Ind. Electron. 2016, 63, 3554-3561. [CrossRef]

8. Park, N.J.; Lee, D.Y.; Hyun, D.S. A power control scheme with constant switching frequency in class-D inverter for induc-tionheating jar application. IEEE Trans. Ind. Electron. 2007, 54, 1252-1260. [CrossRef]

9. Vishnuram, P.; Ramasamy, S.; Sureshkumar, A.; Suresh, P. Phase-Locked Loop-Based Asymmetric Voltage Cancellation for the Power Control in Dual Half-Bridge Series Resonant Inverter Sharing Common Capacitor for Induction Heating Applications. J. Control Autom. Electr. Syst. 2019, 30, 1094-1106. [CrossRef]

10. Trentin, A.; Zanchetta, P.; Clare, J.; Wheeler, P. Automated Optimal Design of Input Filters for Direct AC/AC Matrix Converters. IEEE Trans. Ind. Electron. 2011, 59, 2811-2823. [CrossRef]

11. Hao, L.L.; Hu, A.P.; Covic, G.A. A direct ac-ac converter for inductive power-transfer systems. IEEE Trans. Power Electron. 2012, 27, 661-668.

12. Yamamoto, E.; Hara, H.; Uchino, T.; Kawaji, M.; Kume, T.J.; Jun Koo, K.; Krug, H.P. Development of MCs and its applications in industry. IEEE Ind. Electron. Mag. 2011, 5, 4-12. [CrossRef]

13. Ahmed, N.A.; Nakaoka, M. Boost-half-bridge edge resonant soft switching PWM high-frequency inverter for consumer in-duction heating appliances. Proc. Electr. Power Appl. 2006, 153, 932-938. [CrossRef]

14. Forest, F.; Faucher, S.; Gaspard, J.; Montloup, D.; Huselstein, J.; Joubert, C. Frequency-Synchronized Resonant Con-verters for the Supply of Multiwinding Coils in Induction Cooking Appliances. IEEE Trans. Ind. Electron. 2007, 54, 441-452. [CrossRef]

15. Chen, M.-P.; Chen, J.-K.; Murata, K.; Nakahara, M.; Harada, K. Surge analysis of induction heating power supply with PLL. IEEE Trans. Power Electron. 2001, 16, 702-709. [CrossRef]

16. Sarnago, H.; Óscar, L.; Popa, I.; Burdío, J. Constant-Current Gate Driver for GaN HEMTs Applied to Resonant Power Conversion. Energies 2021, 14, 2377. [CrossRef]

17. Carretero, C.; Lucia, O.; Acero, J.; Burdio, J.M. Phase-shift modulation in double half-bridge inverter with common resonant capacitor for induction heating appliances. IET Power Electron. 2015, 8, 1128-1136. [CrossRef]

18. Komeda, S.; Fujita, H. A Phase-Shift-Controlled Direct AC-to-AC Converter for Induction Heaters. IEEE Trans. Power Electron. 2017, 33, 4115-4124. [CrossRef]

19. Burdio, J.; Barragan, L.; Monterde, F.; Navarro, D.; Acero, J.A. Asymmetrical Voltage-Cancellation Control for Full-Bridge Series Resonant Inverters. IEEE Trans. Power Electron. 2004, 19, 461-469. [CrossRef]

20. Nagarajan, B.; Rama, R.S. CFAVC scheme for high frequency series resonant inverter-fed domestic induction heating system. Int. J. Electron. 2016, 103, 160-176. [CrossRef]

21. Ahmed, N.A. High-Frequency Soft-Switching AC Conversion Circuit with Dual-Mode PWM/PDM Control Strategy for HighPower IH Applications. IEEE Trans. Ind. Electron. 2010, 58, 1440-1448. [CrossRef]

22. Esteve, V.; Kilders, E.S.; Jordan, J.; Dede, E.J.; Cases, C.; Maset, E.; Ejea, J.B.; Ferreres, A. Improving the Efficiency of IGBT Series-Resonant Inverters Using Pulse Density Modulation. IEEE Trans. Ind. Electron. 2011, 58, 979-987. [CrossRef]

23. Forest, F.; Laboure, E.; Costa, F.; Gaspard, J. Principle of a multi-load/single converter system for low power induction heating. IEEE Trans. Power Electron. 2000, 15, 223-230. [CrossRef]

24. Burdio, J.M.; Monterde, F.; Garcia, J.R.; Barragan, L.A.; Martinez, A. A two-output series-resonant inverter for induction-heating cooking appliances. IEEE Trans. Power Electron. 2005, 20, 815-822. [CrossRef]

25. Haerinia, M.; Afjei, E. Investigation of receiving pot core effect on magnetic flux density in inductive coupling-based wireless power transfer. In Proceedings of the 2016 International Symposium on Power Electronics, Electrical Drives, Automation and Motion (SPEEDAM), Institute of Electrical and Electronics Engineers (IEEE), Piscataway, NJ, USA, 24-26 June 2016; pp. 541-545.

26. Cannon, B.L.; Hoburg, J.F.; Stancil, D.D.; Goldstein, S.C. Magnetic Resonant Coupling As a Potential Means for Wireless Power Transfer to Multiple Small Receivers. IEEE Trans. Power Electron. 2009, 24, 1819-1825. [CrossRef] 
27. Zhang, Y.; Lu, T.; Zhao, Z.; He, F.; Chen, K.; Yuan, L. Selective Wireless Power Transfer to Multiple Loads Using Receivers of Different Resonant Frequencies. IEEE Trans. Power Electron. 2015, 30, 6001-6005. [CrossRef]

28. Lyu, Y.L.; Meng, F.Y.; Yang, G.H.; Che, B.J.; Wu, Q.; Sun, L.; Erni, Q.; Li, J.L.-W. A method of using nonidentical resonant coils for frequency splitting elimination in wireless power transfer. IEEE Trans. Power Electron. 2015, 30, 6097-6107. [CrossRef]

29. Choi, W.-K.; Park, C.-W.; Lee, K. Circuit Analysis of Achievable Transmission Efficiency in an Overcoupled Region for Wireless Power Transfer Systems. IEEE Syst. J. 2017, 12, 3873-3876. [CrossRef]

30. Narayanamoorthi, R.; Vimala Juliet, A.; Chokkalingam, B. Cross Interference Minimization and Simultaneous Wireless Power Transfer to Multiple Frequency Loads Using Frequency Bifurcation Approach. IEEE Trans. Power Electron. 2019, 34, 10898-10909. [CrossRef]

31. Vishnuram, P.; Ramasamy, S.; Pradeep, V. Fuzzy Logic-Based Pulse Density Modulation Scheme for Mitigating Uncertainties in AC-AC Resonant Converter Aided Induction Heating System. J. Circuits Syst. Comput. 2018, 28. [CrossRef]

32. Vishnuram, P.; Ramachandiran, G.; Ramasamy, S. A novel power control technique for series resonant inverter-fed induc-tion heating system with fuzzy-aided digital pulse density modulation scheme. Int. J. Fuzzy Syst. 2018, 20, 1115-1129. [CrossRef]

33. Vishnuram, P.; Ramachandiran, G. A simple multi-frequency multiload independent power control using pulse density modulation scheme for cooking applications. Int. Trans. Electr. Energy Syst. 2021, 31, 12771. [CrossRef] 